\title{
WHO CREATES JOBS? SMALL vs. LARGE vs. YOUNG
}

\author{
by \\ John Haltiwanger * \\ University of Maryland and NBER
}

and

Ron S. Jarmin *

U.S. Bureau of the Census

and

Javier Miranda *

U.S. Bureau of the Census

CES 10-17 August, 2010

The research program of the Center for Economic Studies (CES) produces a wide range of economic analyses to improve the statistical programs of the U.S. Census Bureau. Many of these analyses take the form of CES research papers. The papers have not undergone the review accorded Census Bureau publications and no endorsement should be inferred. Any opinions and conclusions expressed herein are those of the author(s) and do not necessarily represent the views of the U.S. Census Bureau. All results have been reviewed to ensure that no confidential information is disclosed. Republication in whole or part must be cleared with the authors.

To obtain information about the series, see www.ces.census.gov or contact Cheryl Grim, Editor, Discussion Papers, U.S. Census Bureau, Center for Economic Studies 2K130B, 4600 Silver Hill Road, Washington, DC 20233, CES.Papers.List@census.gov. 


\begin{abstract}
There's been a long, sometimes heated, debate on the role of firm size in employment growth. Despite skepticism in the academic community, the notion that growth is negatively related to firm size remains appealing to policymakers and small business advocates. The widespread and repeated claim from this community is that most new jobs are created by small businesses. Using data from the Census Bureau Business Dynamics Statistics and Longitudinal Business Database, we explore the many issues regarding the role of firm size and growth that have been at the core of this ongoing debate (such as the role of regression to the mean). We find that the relationship between firm size and employment growth is sensitive to these issues. However, our main finding is that once we control for firm age there is no systematic relationship between firm size and growth. Our findings highlight the important role of business startups and young businesses in U.S. job creation. Business startups contribute substantially to both gross and net job creation. In addition, we find an "up or out” dynamic of young firms. These findings imply that it is critical to control for and understand the role of firm age in explaining U.S. job creation.

* We thank conference and seminar participants at the NBER 2009 Summer Institute Meeting of the Entrepreneurship Working Group, CAED 2009, the World Bank 2009 Conference on Small Firms, NABE Economic Policy Conference 2010, OECD Conference on Entrepreneurship 2010, Queens University and the 2010 WEA meetings for helpful comments. We thank the Kauffman Foundation for financial support. Any opinions and conclusions expressed herein are those of the author(s) and do not necessarily represent the views of the U.S. Census Bureau. All results have been reviewed to ensure that no confidential information is disclosed.
\end{abstract}




\section{Introduction}

An enduring notion about the U.S. economy is that small businesses create most private sector jobs. The notion of an inverse relationship between firm size and growth, while popular among politicians ${ }^{1}$ and small business advocates, runs counter to that described by Gibrat's Law (see Sutton 1997) that states the firm growth rates are independent of firm size. Attempts to definitively describe the firm size - firm growth relationship empirically have yielded mixed results.

Early empirical support for small firm dominance in net job creation comes from the studies by Birch (1979, 1981, and 1987) finding that growth is inversely related to firm size. In the years since Birch’s early work, a number of studies have demonstrated that empirical analyses of the firm size - firm growth relationship are subject to a host of statistical and measurement issues that affect how they are interpreted. For example, Davis, Haltiwanger and Schuh (1996) (hereafter DHS) highlight several issues that, once accounted for, break the inverse relationship (at least for U.S. manufacturing firms) between firm size and job creation that Birch described.

The statistical and measurement issues documented by DHS and other studies ${ }^{2}$ can be grouped into the following categories. The first is data suitability - can firm size and growth be measured accurately in available data products? Second, many analyses fail to properly distinguish between gross and net growth rates where, typically, small net changes in employment across firms mask large gross changes, both positive and negative, within and

\footnotetext{
${ }^{1}$ Statements that small businesses create most net new jobs are ubiquitous by policymakers. A common claim by policymakers is that small businesses create 2/3 or more of net new jobs. Every President since President Reagan has included such statements in major addresses (often in the State of the Union addresses to Congress) and many other leaders in the U.S. House and Senate have made similar remarks. A list of selected quotes from speeches is available upon request.

${ }^{2}$ For example, Brown, Hamilton and Medoff (1990) raise many of the same statistical issues as DHS but also explore the employer size wage differential.
} 
across groups of firms. Third, the interaction of typical firm size classification methods and regression to the mean - the tendency of firms experiencing a growth shock in one period to experience an opposite one in the next period - biases the allocation of job growth across firms to smaller units. These categories are not mutually exclusive; however, they have different implications for the interpretation of the various data sources and methodologies used to study firm size and growth.

Neumark, Wall and Zhang (2009) (hereafter NWZ) recently performed a very careful analysis where they avoid the misleading interpretations of the data highlighted by DHS. Using NETS data covering the entire U.S. private sector from 1992 to 2004, they find an inverse relationship between net growth rates and firm size. This contrasts with the finding for U.S. manufacturing over earlier periods in DHS.

In this paper, we demonstrate there is an additional critical issue that clouds the interpretation of previous analyses of the relationship between firm size and growth. Datasets traditionally employed to examine this relationship contain limited or no information about firm age. Our analysis emphasizes the role of firm age and especially firm births in this debate ${ }^{3}$ using comprehensive data tracking all firms and establishments in the U.S. non-farm business sector for the period 1976 to 2005 from the Census Bureau’s Longitudinal Business Database (LBD). We are the first to use the comprehensive LBD to study these issues. As will become clear, the LBD is uniquely well-suited to study these issues on an economy-wide basis.

\footnotetext{
${ }^{3}$ An important early study that also emphasized the role of firm age for growth dynamics is Evans (1987). The latter paper found an inverse relationship between firm growth and size and age using firm level data for U.S. manufacturing firms. As Evans points out, the work is based on data with substantial limitations but interestingly some aspects of his findings hold for our data that does not suffer from the same limitations. Specifically, the departures from Gibrat's Law are primarily for young and small firms. A variety of other studies have also examined the role of employer age for employer dynamics and employment growth including Dunne, Roberts and Samuelson (1989), Haltiwanger and Krizan (1999), Acs, Armington and Robb (1999). These latter studies focused on establishment-age.
} 
Our main findings are summarized as follows. First, consistent with NWZ, when we only control for industry and year effects, we find an inverse relationship between net growth rates and firm size, although we find this relationship is quite sensitive to regression to the mean effects. Second, once we add controls for firm age, we find no systematic relationship between net growth rates and firm size. A key role for firm age is associated with firm births. We find that firm births contribute substantially to both gross and net job creation. Importantly, because new firms tend to be small, the finding of a systematic inverse relationship between firm size and net growth rates in prior analyses is entirely attributable to most new firms being classified in small size classes.

Our findings emphasize the critical role played by startups in U.S. employment growth dynamics. We document a rich "up or out” dynamic of young firms in the U.S. That is, conditional on survival, young firms grow more rapidly than their more mature counterparts. However, young firms have a much higher likelihood of exit so that the job destruction from exit is also disproportionately high among young firms. More generally, young firms are more volatile and exhibit higher rates of gross job creation and destruction.

These findings highlight the importance of theoretical models and empirical analyses that focus on the startup process - both the process of entry itself but also post-entry dynamics especially in the first ten years or so of a firm’s existence. This is not to deny the importance of understanding and quantifying the ongoing dynamics of more mature firms but to highlight that business startups and young firms are inherently different.

The paper proceeds as follows. In section 2, we provide further background on the literature. Section 3 describes the data. Section 4 presents the main empirical results. Section 5 provides concluding remarks. 


\section{Background}

Much of the support for the hypothesis of an inverse relationship between employer size and growth comes from interpreting patterns observed in public-use data products. An example is the Census Bureau's Statistics of U.S. Business (SUSB) that is released in partnership with the Small Business Administration ${ }^{4}$. However, as demonstrated by NWZ and confirmed below, this finding can also be obtained from a careful analysis of business micro data. In this section we review the data and measurement issues in prior studies of firm size and growth and describe the characteristics of datasets suited to such analyses. We then briefly highlight findings from the Census Bureau’s new Business Dynamics Statistics (BDS). This new public-use product gives data users a much richer window on the interactions of size, age and growth that was previously only available to those with access to restricted use data.

\subsection{Review of Data and Measurement Issues}

Analyses of the relationship between firm size and growth have been hampered by data limitations and measurement issues. As a consequence these studies fail to emphasize a much richer description of the firm dynamics associated with the creative destruction process prevalent in market economies. Results from the new public-use BDS as well as from its underlying source data, the LBD, reveal a more accurate picture of firm dynamics with a more limited role for firm size. This section describes the basic characteristics of these data and how we address some of the limitations of prior analysis.

The analytical power of the LBD and data products constructed from it for understanding firm dynamics comes from its ability to accurately track both establishments and their parent

\footnotetext{
${ }^{4}$ SUSB data are available at http://www.census.gov/econ/susb/index.html.
} 
firms over time ${ }^{5}$. This is a critical feature of the data since it is very difficult to discern the relationships of interest using only either firm or establishment level data. Measures of job growth derived solely from establishment-level data have the virtue that they are well-defined; when we observe an establishment grow we know there are net new jobs at that establishment. In contrast, job growth observed in firm-level data may reflect the many changes in ownership stemming from mergers, acquisitions and divestitures that are ubiquitous features of market economies. Having only establishment-level data is inadequate as well. If the only data available are at the establishment level, the relationship between growth and the size and age of the establishment may be not provide much information about the relevant firm size and firm age. A large, national retail chain is a useful example. In retail trade, a firm's primary margin of expansion is opening new stores rather than the expansion of existing stores (see Doms, Jarmin and Klimek (2004), Foster, Haltiwanger and Krizan (2006) and Jarmin, Klimek and Miranda (2009)). This implies there are many new establishments of existing firms and for the core issues in this paper, the growth from such new establishments should be classified based upon the size and age of the parent firm, not the size and age of the establishment. Much of the literature on employer size and net growth has primarily been based on establishment-level or firm-level data but not both. ${ }^{6}$ Tracking the dynamics of both firms and their constituent

\footnotetext{
${ }^{5}$ For purposes of this discussion as well as the subsequent empirical analysis, we use the definitions of establishments and firms as defined by the U.S. Census Bureau. Specifically, an establishment is a specific physical location where business activity occurs while a firm reflects all the establishments under common operational control.

${ }^{6}$ DHS analysis is restricted to U.S. manufacturing establishments although they were able to construct a measure of firm size at the manufacturing level. Dunne, Roberts and Samuelson (1989) examine the role of establishment size and age for the growth and failure of U.S. manufacturing plants. Evans (1987) used firm-level continuers for U.S. manufacturing firms over the 1976-1980 period. Birch $(1979,1981,1997)$ uses the D\&B data that has both firm and establishment-level information although subject to the limitations of the D\&B data. NZW use the NETS data that has both firm and establishment-level information.
} 
establishments permits clear and consistent measures of firm growth as well as firm entry and exit. $^{7}$

Even with rich source data such as the Census Bureau's BR, a key challenge in analyzing establishment and firm dynamics is the construction and maintenance of high quality longitudinal linkages that allow accurate measurement of establishment and firm births and deaths. Given the ubiquitous changes in ownership among U.S. firms, a common feature observed in business micro data is spurious firm entry and exit caused by purely legal and administrative actions. Early versions of the D\&B data used by Birch were plagued with these limitations which hampered the ability of researchers to distinguish between real business dynamics and events triggered by legal or business transactions such as credit applications (see, Birley (1984) and Alrdrich et. al. (1988) for detailed discussion). The NETS data used by NZW is based on a much improved version of the $\mathrm{D} \& \mathrm{~B}$ data although there are some open questions about the nature of the coverage in NETS. ${ }^{8}$ For our analysis, we minimize the impact of these data quality issues by utilizing the LBD’s high quality longitudinal establishment linkages and its within-year linkages of establishments to their parent firms.

DHS recognized the statistical pitfalls in relating employer size and growth. One issue they highlight is the role of regression to the mean effects. Businesses that recently experienced negative transitory shocks (or even a transitory measurement error) are more likely to grow while businesses recently experiencing positive transitory shocks are more likely to shrink. This effect

\footnotetext{
${ }^{7}$ In our analysis, firm entry is defined when all of the establishments at that firm are de novo establishment entrants. Likewise, firm exit is defined when all of the establishments at that firm cease operations.

${ }^{8}$ NWZ report about 13.1 million firms and 14.7 million establishments in a typical year. The LBD (and the closely related County Business Patterns) report about 6 million firms and 7 million establishments in a typical year that have at least one paid employee. The Census Bureau also reports more than 15 million additional nonemployer businesses in a typical year. It appears that NETS is some combination of employer and nonemployer businesses but does not reflect the universe of businesses. For our purposes, we focus on employer businesses. For discussion of the importance of nonemployer businesses and the relationship between nonemployer and employer businesses see Davis et. al. (2009). There also remain questions about how well NETS captures startups especially for small businesses.
} 
alone will yield an inverse relationship between size and growth. Friedman (1992) states this type of regression fallacy "is the most common fallacy in the statistical analysis of economic data”. This issue is particularly relevant when studying the business size - growth relationship and is manifest in the method used to classify businesses into size classes in many commonly used data sources. The early work by Birch and others classified businesses into size classes using base year employment; a method now known to yield results that suffer from regression to the mean.

DHS propose an alternative classification method to mitigate the effects of regression to the mean. They note that, while base year size classification yields a negative bias, using end year size classification yields a positive bias. To avoid the bias, negative or positive, DHS propose using a classification based on current size where current size is based on the average of employment in year $t-1$ and $t$. Using current size is a compromise between using year $t-1$ (base) or (end) year $t$ size to classify firms.

Even though current-year (average) size is a compromise, it has limitations as well. Firms that are impacted by permanent shocks that induce the firm crossing over multiple size class boundaries between $t-1$ and $t$ will be classified into a size class that is in between the starting and ending size class. Recognizing this potential limitation, the Bureau of Labor Statistics has developed a dynamic size classification methodology (see Butani et. al. (2006)). ${ }^{9}$ Specifically, the methodology attributes job gains or losses to each of the size classes that the firm passes through in its growth or contraction. Interestingly, the findings that compare results

\footnotetext{
${ }^{9}$ Related evaluation work on alternative methodologies by BLS is found in Okolie (2004). We also note that the BLS BED series releases net and gross job quarterly flows by a firm size measure. The firm size measure they use is based on a taxpayer ID definition of the firm so that for multi-unit establishment firms that have multiple taxpayer Ids their firm definition is somewhere between the establishment and overall firm.
} 
across size-classification methods (see Butani et. al. (2006)) show the current (DHS) and dynamic (BLS) size classification methodologies yield very similar patterns.

In what follows, we present results using both the base year and current size class methodologies. This discussion, as well as our findings from using both methodologies, leads us to prefer the current size class methodology as it is inherently more robust to regression to the mean effects. However, we report the base year methodology for purposes of reference and also to explore the sensitivity of the results to this methodological issue.

DHS also emphasize avoiding inferences that arise from the distinction between net and gross job creation. Policy analysts are inherently tempted to want to make statements along the lines that "Small businesses account for X percent of net job creation". The problem with this approach is that since gross job flows dwarf net job flows, many different groupings of establishments can account for a large share the net job creation. For example, the annual net employment growth rate for U.S. nonfarm private sector business establishments between 1975 and 2005 averaged at 2.2 percent. Underlying this net employment growth rate were establishment-level average annual rates of gross job creation and destruction of 17.6 percent and 15.4 percent, respectively (statistics from the BDS which are described below). Decomposing net growth across groups of establishment or firms is problematic (at least in terms of interpretation) when some shares are negative. We elaborate on these issues in the next subsection by taking a closer look at the Census Bureau’s new BDS data.

\subsection{Overcoming data and measurement issues with the BDS}

To help illustrate these points before proceeding to the more formal analysis, we examine some tabular output from the BDS on net job creation by firm size and firm age. The precise definitions of firm size and firm age are discussed below (and are described on the BDS website 
http://www.ces.census.gov/index.php/bds). Table 1 shows the number of net new jobs by firm size and firm age class in 2005. The upper panel shows the tabulations using the base year size method and the lower panel the current year size method. The table yields a number of interesting observations. About 2.5 million net new jobs were created in the U.S. private sector in 2005. Strikingly, firm startups (firms with age 0) created about 3.5 million net new jobs. In contrast, every other firm age class except for the oldest firms exhibited net declines in employment. ${ }^{10}$ However, it would be misleading to say that it is only firm startups and the most mature firms that contributed to job gains. In both panels there are large positive numbers in many cells but also large negative numbers in other cells. It is also clear that there are substantial differences in these patterns depending on using the base year or current year size method although some common patterns emerge. For example, excluding startups, firms that have employment between 5 and 99 workers consistently exhibit declines in net jobs.

The patterns reflect two basic ingredients. Obviously, whether the size/age class contributes positively or negatively depends on whether that size/age class has a positive or negative net growth rate. In addition, the magnitude of the positive or negative contribution depends, not surprisingly, on how much employment is accounted for by that cell. That is, a size/age class may have a large positive number not so much because it has an especially high growth rate but because it accounts for a large fraction of employment (e.g., a 1 percent growth rate on a large base yields many net new jobs).

\footnotetext{
${ }^{10}$ A review of the BDS statistics for other years shows that the net job creation contribution of the oldest businesses
} is highly procyclical. 
Figure 1 summarizes these patterns in the BDS over the 1992 to 2005 period by broad size and age classes. ${ }^{11}$ Figure 1 shows the fraction of job creation and job destruction accounted for by small (less than 500 workers) and large firms (500 workers and above) broken out by whether they are firm births, young firms (less than 10 year old firm) or mature firms (10 years and above). Also included is the share of employment accounted for by each of these groups. We focus on gross job creation and destruction at the establishment-level but classified by the characteristics of the firms that own them.

Several observations emerge. First, for the most part the fraction of job creation and destruction accounted for by the various groups is roughly proportional to the share of employment accounted for by each group. For example, it is the mature and large firms that account for most employment (about 45 percent) and most job creation and destruction. This observation, while not surprising, is important in the debate about what classes of businesses create jobs. The basic insight is that the firms that have the most jobs create the most jobs - so if a worker is looking for the places where the most jobs are being created they should go where the jobs are - large and mature firms. This is not the whole story of course, as what we are primarily interested in is whether any identifiable groups of firms disproportionately create or destroy jobs. The rest of the paper is a rigorous examination of this issue. However, Figure 1 nicely previews some of our primary findings. Young firms disproportionately contribute to both job creation and job destruction. Included among young firms are firm births which, by definition, contribute only to job creation. Nearly all firm births are small. ${ }^{12}$ Before the BDS, all publicly available data that could be used to look at the role of firm size in job creation were

\footnotetext{
${ }^{11}$ We use the base year size method in Figure 1. The results in Figure 1 are robust to using either of the size classification methods discussed in the analysis below. Precise definitions of job creation and destruction are provided below.

${ }^{12}$ Some large births are present in the data. These are unusual but appear to be legitimate often operating as professional employer organizations.
} 
silent on the age dimension. As such, it is easy to see how analysts perceived an inverse relationship between size and growth in the data. We now turn to a more systematic and rigorous analysis that takes advantage of the rich micro data contained in the Longitudinal Business Database.

\section{The Longitudinal Business Database}

The Longitudinal Business Database (LBD) underlies the public use statistics in the BDS just discussed. As the last section suggested, many of the patterns we discuss in this paper can be readily seen in the public domain BDS. ${ }^{13}$ However, we use the LBD micro data rather than the BDS so we can control for detailed industry effects in our analysis.

The LBD covers all business establishments in the U.S. private non-farm economy that file payroll taxes with the IRS. As such, it covers the universe of establishments in the U.S. nonfarm business sector with at least one paid employee. ${ }^{14}$ The LBD begins in 1976 and currently runs through 2005 (as of the time when we conducted the analysis for this paper) and includes information on detailed industry for every establishment. In the current paper, we use 4-digit SIC codes through 2001 and 6-digit NAICS codes after that. We note that the LBD (and in turn the BDS) employment and job creation numbers track closely those of the County

Business Patterns and Statistics of U.S. Business programs of the U.S. Census Bureau (see Haltiwanger, Jarmin and Miranda (2009) as they all share the Census Bureau's Business Register (BR) as their source data. However, due to design features and differences in processing, in

\footnotetext{
${ }^{13}$ We use classifications not currently available in the BDS. For example, we control for detailed industry (4-digit SIC or 6-digit NAICS as appropriate) in our analysis. Currently, the BDS only releases tabulations at the broad sector level. We have replicated our main findings using an extended version of the BDS with cell based regressions at the detailed industry, age and size level of aggregation. We have also found that the basic patterns we report also hold using the public domain BDS controlling only for broad sector.

${ }^{14}$ This is one clear distinction with the NETS database which apparently includes both employer and nonemployer businesses (but also apparently not the universe of both).
} 
particular the correction of longitudinal establishment and firm linkages, the statistics generated from the LBD will diverge slightly from those in CBP and SUSB.

The unit of observation in the LBD is the establishment defined as a single physical location where business is conducted. Each establishment-year record in the LBD has a firm identifier associated with it so it is possible to track the ownership structure of firms in any given year as well as changes over time. Firms can own a single establishment or many establishments. In some cases these firms span multiple geographic areas and industries. Establishments can be acquired, divested or spun off into new firms so the ownership structure of firms can be very dynamic and on occasion complex. We use these firm level identifiers to construct firm level characteristics for each establishment in the LBD. Further details about the LBD and its construction can be found in Jarmin and Miranda (2002).

\subsection{Measuring Firm Age and Firm Size}

The construction of firm size measures is relatively straightforward. Firm size is constructed by aggregating employment across all establishments that belong to the firm. Employment for each establishment is obtained from administrative sources or Census collections. Employment represents the number of employees on payroll during the pay period including March 12. In this sense it is not unlike employment measures in other databases such as the County Business Patterns (CBP), the Current Establishment Survey (CES) and the Quarterly Census of Employment and Wages (QCEW).

As discussed above, we measure firm size using both the base year and current size methodologies. For base year firm size, we use the firm size for year $t-1$ for all businesses except for new firms. For new firms, we follow the approach used by Birch and others and 
allocate establishments belonging to firm startups to the firm size class in year t. For current size, we use the average of firm size in year $t-1$ and year $t$.

The construction of firm age presents more difficult conceptual and measurement challenges. We follow the approach adopted for the BDS and based on our prior work (see, e.g., Becker et. al. (2006) and Davis et. al. (2007)). Namely, when a new firm ID arises for whatever reason, we assign the firm an age based upon the age of the oldest establishment that the firm owns in the first year the new firm ID is observed. The firm is then allowed to age naturally (by one year for each additional year it is observed in the data) regardless of mergers or acquisitions and as long as the firm ownership and control does not change. An advantage of this approach is that firm births as well as firm deaths are readily and consistently defined. That is, a firm birth is defined as a new firm ID where all the establishments at the firm are also births. Similarly, a firm death is defined as when a firm ID disappears and all of the establishments associated with that firm ID exit.

A strength of our firm size and age measures is that they are robust to ownership changes. For a pure ownership change with no change in activity, there will be no spurious changes in firm size or firm age. When there are mergers, acquisitions, or divestitures, firm age will reflect the age of the appropriate components of the firm. Firm size will change but in a manner also consistent with the change in the scope of activity. In section 3.2 below, we provide further discussion on how our measurement methodology yields patterns of the relationship between net growth, firm size and firm age that are robust to ownership changes and M\&A activity.

Before proceeding, we note that in the current paper we focus on growth dynamics of establishments and firms over the 1992 to 2005 period. We limit our analysis to this period so that we can define firm age consistently over the period for all establishments with firm age less 
than 15 years. We also include a category for establishments belonging to firms that are 16 years or older (in 1992 these are the firms with establishments in operation in 1976 and for which we can not give a precise measure of firm or establishment age).

\subsection{The Establishment-Level and Aggregate Growth Rate Concepts}

This section describes the establishment and firm-level growth rate measures we use in the paper in more detail. Let $E_{i t}$ be employment in year $t$ for establishment $i$. In the LBD, establishment employment is a point-in-time measure reflecting the number of workers on the payroll for the payroll period that includes March 12th. We measure the establishment-level employment growth rate as follows:

$g_{i t}=\left(E_{i t}-E_{i t-1}\right) / X_{i t}$,

where

$$
X_{i t}=.5 *\left(E_{i t}+E_{i t-1}\right) \text {. }
$$

This growth rate measure has become standard in analysis of establishment and firm dynamics, because it shares some useful properties of log differences but also accommodates entry and exit. (See Davis et al 1996, and Tornqvist, Vartia, and Vartia 1985). ${ }^{15}$ In what follows, we refer to $g_{i t}$ as the DHS growth rate measure and $X_{i t}$ as the DHS denominator.

Note that the DHS growth rate measure can be flexibly defined for different aggregations of establishments. We first discuss the measures of net growth used in the analysis. In particular, consider the following relationships

$$
g_{t}=\sum_{s}\left(X_{s t} / X_{t}\right) g_{s t}=\sum_{s}\left(\left(X_{s t} / X_{t}\right) \sum_{i \in s}\left(X_{i t} / X_{s t}\right) g_{i t}\right)
$$

\footnotetext{
${ }^{15}$ The DHS growth rate like the log first difference is a symmetric growth rate measure but has the added advantage that it accommodates entry and exit. It is a second order approximation of the log difference for growth rates around zero. A key property is that it is a symmetric growth rate like log first differences but unlike the standard growth rate. Note that the use of a symmetric growth rate does not obviate the need to be concerned about regression to the mean effects. Also, note the DHS growth rate is not only symmetric but bounded between -2 (exit) and 2 (entrant).
} 
where

$$
X_{t}=\sum_{s} X_{s t}=\sum_{s} \sum_{i \in s} X_{i t}
$$

where $g_{t}$ is the aggregate DHS growth rate and $s$ indexes classifications of establishments into groups defined for any level of aggregation $s$ where $s$ can refer to firm, industry, firm size, or firm age classifications. Thus, the DHS net growth rates for various aggregations of interest are just properly weighted sums of establishment-level growth rates where the establishment is the lowest level of aggregation in the LBD. Important groupings for this paper include firms and firm size and age categories.

Before discussing components of the DHS net growth that we use in our analysis, it is important to discuss how computing DHS net growth rates at different levels of aggregation can affect interpretation. We are interested in computing net growth rates at both the establishment and firm levels. In the LBD, we have access to both levels of data where the establishment structure of the firms is well specified. In other settings, however, the analyst may have access to only establishment, or only firm-level data. Thus, it is critical to understand how using one or the other can affect interpretation.

An important difference in computation and interpretation arises when establishments undergo changes in ownership due to mergers, divestitures or acquisitions. In these instances, net growth rates computed from firm-level data alone will reflect changes in firm employment due to adding and/or shedding continuing establishments. This occurs even if the added and/or shed establishments experience no employment changes themselves.

To avoid this problem we compute firm growth rates as suggested in the expressions above. Namely, the period $t-1$ to period $t$ net growth rate for a firm is the sum of the appropriately weighted DHS net growth rate of all establishment owned by the firm in period $t$, 
including new acquisitions, plus the net growth attributed to establishments owned by the firm in period $t-1$ that it has closed before period $t$. For any continuing establishment that changes ownership, this method attributes any net employment growth to the acquiring firm. Note, however, if the acquired establishment exhibits no change in employment there will be no accompanying change in firm level employment induced by this ownership change. The general point is that this method for computing firm-level growth captures only "organic" growth at the establishment-level and abstracts from M\&A activity.

An example helps to cement ideas. The graphic in the left panel of Figure 2 describes the period $t-1$ to period $t$ dynamics for twelve hypothetical establishments owned by 8 hypothetical firms. The patterns reflected in the example are typical of the patterns one sees in actual establishment and firm dynamics datasets such as the LBD. The right hand panel gives the results of calculations using the above formulas at the firm and establishment level of aggregation.

In this example, establishments 1,2,4,5, 9, 11 and 12 are continuers. Establishments 3, 8 and 10 are deaths and establishments 6 and 7 are births. Establishment 2 is divested from firm A and acquired by firm B. A new firm, C, enters with establishment 7 and firm D dies by shutting down its only establishment (8). Firm B opens a new establishment (6), firm E closes one of its establishments (10), and firm $\mathrm{G}$ changes ownership and becomes firm $\mathrm{H}$.

Using the above formulas, we compute the firm-level net growth rates two ways: first, using firm-level data without correcting for M\&A activity and second, using the employmentweighted establishment-level data that only incorporates organic growth. Looking at the resulting rates in the lower right of Figure 4, we see that the implied net growth rates are equal for all but firms A, B, G and $\mathrm{H}$. As mentioned above, firms experiencing M\&A activity (A and 
B) will have inflated absolute net growth rates when computed using the first method. Similarly, firm-level computations in the presence of pure ownership changes using the first method will result in spurious job creation and destruction due simply to the transfer of ownership of the affected establishment(s). For example, using the first method, firm A is assigned a decrease in employment of 130 or just over $25 \%$ of current size employment. If instead, we compute the firm net growth rates as the weighted sum of the establishment rates, firm A has a decrease in employment of 30 workers of just over $6 \%$. This is the net of the increase in 50 employees at establishment 1 and the loss of 80 employees from the shutdown of establishment 3. Note that the decrease in employment at establishment 2 is assigned to firm B since it is the controlling firm in period $t$. Firm B then is assigned a net change in employment of 45 or $17 \%$ of current size employment. Finally, in the case of a simple change in ownership where firm G is bought out by firm $\mathrm{H}$, the only affected establishment (12) grows by $18 \%$, but the first method approach results in values of -2 and 2 .

Computing firm growth rates building up from establishment-level growth rates produces consistent measures that are robust to ownership changes which is important when we want to compare across industries, geographic entities and firm or establishment size and age categories. More fundamentally it also has strong implications for how we interpret the different margins of adjustment. The bottom panel of Figure 4 makes the point. It decomposes aggregate net growth into growth coming from firm birth and death events as well as from continuing firms. Measures that fail to account for the effects of M\&A activity will overestimate employment changes from these margins. 
As just discussed, we are interested in examining both net and gross employment

changes. The basic DHS growth rate calculations given above form the basis of examining gross changes. Measures of job creation and destruction at the establishment level are given by:

$$
\begin{aligned}
& J C_{i t}=\max \left(g_{i t}, 0\right) \\
& J D_{i t}=\max \left(-g_{i t}, 0\right)
\end{aligned}
$$

Job creation from entry at the establishment level is given by:

$$
J C_{i t}=\max \left(g_{i t}, 0\right) * I\left\{g_{i t}=2\right\}
$$

where $I$ is an indicator variable equal to one if expression in brackets hold, zero otherwise, and $g_{\text {it }}$ $=2$ denotes an entrant. Similarly job destruction from exit at the establishment level is given by:

$$
J D_{i t}=\max \left(-g_{i t}, 0\right) * I\left\{-g_{i t}=2\right\}
$$

where $g_{i t}=-2$ denotes an exit.

Using these measures it is straightforward to generate aggregate measures of job creation and destruction as well as job creation and destruction from entry and exit, respectively (at any level of aggregation) given by:

$$
\begin{aligned}
& J C_{t}=\sum_{i}\left(X_{i t} / X_{t}\right) \max \left\{g_{i t}, 0\right\} \\
& J D_{t}=\sum_{i}\left(X_{i t} / X_{t}\right) \max \left\{-g_{i t}, 0\right\} \\
& J C_{-} \text {Entry }_{t}=\sum_{i}\left(X_{i t} / X_{t}\right) I\left\{g_{i t}=2\right\} \max \left(g_{i t}, 0\right) . \\
& J D_{-} \text {Exit }_{t}=\sum_{i}\left(X_{i t} / X_{t}\right) I\left\{g_{i t}=-2\right\} \max \left(-g_{i t}, 0\right)
\end{aligned}
$$

Given these definitions, the following simple relationships hold:

$$
g_{t}=J C_{t}-J D_{t}, J C_{t}=J C_{-} \text {Cont }_{t}+J C_{-} \text {Entry }_{t} \text { and } J D_{t}=J D_{-} \text {Cont }_{t}+J D_{-} \text {Exit }_{t}
$$


where JC_Cont and JD_Cont are job creation and job destruction for continuing establishments respectively.

We can also define job creation and destruction starting from the firm level in a manner analogous to the relationships above. As with net changes in the presence of M\&A activity, appropriate care must be used in considering the relationship between establishment-level and firm-level employment gross rate patterns. But even after focusing on only organic growth, there are inherent differences in firm and establishment-level gross rates of creation and destruction. Firms that are expanding (including firm entrants) contribute to firm-level gross job creation and firms that are contracting (including firm exits) contribute to firm-level gross job destruction. But a firm that is expanding may have some contracting (or exiting) establishments and a firm that is contracting may have some expanding (or entering) establishments. As such, gross job creation and destruction is inherently greater when summed up from establishment-level net changes than when summed up from firm-level net changes. In a closely related way, we note that firm entry implies that there must be establishment entry as an entering firm is identified as a new firm with all new establishments but the converse does not hold. Similarly, firm exit implies that there must be establishment exit but the converse does not hold.

The distributions of firm and establishment-level employment growth rates that emerge from this measurement approach exhibit substantial dispersion driven in part by a high pace of establishment and firm level entry and exit. ${ }^{16}$ Another feature of this dispersion is that the distributions exhibit fat tails with a large fraction of job creation being accounted for by rapidly growing firms and establishments and a large fraction of job destruction being accounted for by

\footnotetext{
${ }^{16}$ For the sake of brevity, the depictions of these distributions and a more thorough discussion is in the web appendix. The web appendix can be found at http://econweb.umd.edu/ haltiwan/Web_Appendix_for_size_age_paper_august13.pdf. In the remainder of the document we simply refer to this as the web appendix. Figure W.1 in the web appendix shows the establishment and firm-level growth rate distributions on a weighted and unweighted basis.
} 
rapidly contracting firms and establishments. Characterizing the role of firm size and firm age in accounting for these patterns is the focus of this analysis to which we now turn.

\section{The Relationship between Employment Growth, Firm Size and Firm Age}

Our primary objective is to understand the relationship between net employment growth, and its components, and firm size and age. In this section, we use a non-parametric regression approach to quantify these relationships. In our main specification, we regress net employment growth at the firm-level on firm size classes by themselves, on firm age classes by themselves and by firm size and age together. We focus on employment-weighted specifications since this enables the coefficients to be interpreted in terms of the impact on net employment growth rates at the aggregate level for the specified category. Since firm size and firm age distributions vary by industry as do net growth rate patterns, we control for detailed industry fixed effects. ${ }^{17}$ In addition, to abstract from cyclical or secular aggregate considerations we control for year effects. Given our non-parametric approach with firm size, firm age, industry and year fixed effects, our results are readily interpretable as employment-weighted conditional means. As such, we can replicate all of the results in what follows using a cell-based regression approach where net growth rates are measured at the industry, firm size, firm age, and year level of aggregation.

\subsection{Net Employment Growth and Firm Size}

We report our base set of results on the role of firm size and firm age for net firm level job creation in Table 2. Note that the results reported in Table 2 are based on regressions including more than 70 million firm-year observations and consequently the standard errors for

\footnotetext{
${ }^{17}$ Detailed industry effects are at the 4-digit SIC level for years through 2001 and at the 6-digit NAICS level for years after 2001. For the firm-level regressions, we classify firms into their modal detailed industry (the industry with the largest employment share). To avoid spuriously allocating a firm to a broad industry that it has little overall activity but a relatively large detailed industry share, we classify firms hierarchically. That is, we first find the modal 2-digit industry, then within the 2-digit the modal 3-digit industry and so on. Note that we also estimate the main specifications at the establishment-level where industry misclassification is not an issue and obtain virtually identical results (see Table W.1 in the web appendix).
} 
the estimates are very small. Rather than report individual standard errors we simply note that the largest standard error in the table is less than 0.0005. This pattern holds throughout the results reported in the remainder of the paper and the web appendix so we do not repeat the reporting of standard errors.

There are a large number of coefficients reported in Table 2 given the alternative specifications and the detailed non-parametric size and age classes. We find it easier to discuss the results with the aid of figures that illustrate the patterns of estimated coefficients. In interpreting the figures that follow it is important to recall that the estimated coefficients in Table 2 represent differences relative to an omitted group. However, to facilitate the interpretation of the magnitudes, we report the omitted group at its unconditional mean rather than zero. In turn, we simply rescale the other estimated coefficients by adding the value of the unconditional mean for the omitted category (e.g., the 10,000+ firm size class). Adding the unconditional mean to all categories does not distort the relative differences but provides perspective about the magnitude of the effects.

Figure 3 shows the relationship between net employment growth and firm size across the specifications estimated in Table 2. The upper panel displays results from the regressions in Table 2 for all firms. The lower panel displays the size coefficients from the same regressions limited to the sample of continuing firms only. Beginning with the main results in the upper panel, the plotted curve for the base-year size specification without age controls (column 1 of Table 2) shows a strong inverse relationship between firm size and net employment growth. The average annual rate of net employment growth in the smallest size class is 18.9 percentage points higher than that for the largest size firms (10,000 or more employees). The effect declines more or less monotonically as the size of the firm increases. The relative net employment growth 
premium for being small declines to 6.2 percent, 3.4 percent and 1.9 percent for size classes 5-9, 10-19 and 20-49 respectively. It remains less than 1 percent for the larger size classes.

As argued above, however, the base-year method has several undesirable attributes for examining firm size and growth. The curve plotting the estimated coefficients from our preferred current-year (average) size specification (column 2 of Table 2) shows the inverse relationship remains but the quantitative relationship is substantially muted. Comparing the base and current size results suggest the effects of regression to the mean are quite strong in the smallest size classes. In Figure W.2 of the web appendix, we show that, consistent with these patterns, the negative serial correlation of firm level net employment growth rates is especially large in absolute value for small firms. But the more general point is that, in the absence of controls for firm age, we obtain similar qualitative results as those in NZW. That is, size classification methodology matters but there still is an inverse relationship between net employment growth and firm size when not controlling for firm age.

Controlling for firm age, however, has a dramatic impact on these patterns (columns 4 and 5 of Table 2). Regardless of the size classification methodology, once we control for firm age we observe no systematic relationship between net growth and firm size. When we use base year size, the smallest size class has the largest positive coefficient but the size classes in the range from 5 to 499 have the most negative coefficients. This implies that firms in the 5 to 499 range have lower net growth rates on average than the largest businesses, once we control for firm age. When we use current size, we also don't observe a monotonic relationship, but we do find a positive relationship between net growth and firm size for all the size classes up through 500 workers. While the details differ non-trivially depending on which size class method we 
use, the main point is that, once we control for firm age, there is no evidence that small firms systematically have higher net growth rates than larger businesses. ${ }^{18}$

In the lower panel of Figure 3 we show the results ${ }^{19}$ when we restrict the analysis to continuing firms only. The first thing to note is that there is a less dramatic impact of controlling for firm age since there is, by construction, no role for startups. For base year size methods whether or not there is a control for firm age, there is a strong inverse relationship between net growth and firm size for continuing firms. However, using current size, there is a positive relationship between net firm growth and firm size regardless of whether one controls for firm age. Hence, for continuing firms, it is primarily the size class methodology that matters. The stark differences for small continuing firms between the base size and current size results are consistent with the strong regression to the mean effects for these firms. It is also worth noting that some of the differences between the patterns across the two panels reflect the role of firm exits. We draw out the role of firm exits by firm size and age in results discussed below. Before turning to firm age patterns, it is of interest to examine Figure 3 in light of Gibrat's law. Figure 3 suggests that Gibrat's law (the prediction that firm growth should be independent of size) holds approximately if we exclude the smallest firms especially if we use the current size measure and we don't control for firm age. That is, departures arise for the smallest firms (where regression to the mean effects are especially an issue), and for entering and young firms which as we will see below have their own interesting dynamic not well captured by the models underlying the predictions of Gibrat’s law (see, e.g., Sutton (1997)).

\subsection{Net Employment Growth and Firm Age}

\footnotetext{
18 The patterns in Table 2 are, not surprisingly, roughly consistent with the simple tabulations from the BDS in Table 1 where we observed many negative net job cells for smaller businesses abstracting from startups. We also note that in the web appendix we show the patterns in Table 2 are robust to estimating employment-weighted establishment level results.

${ }^{19}$ Regression coefficients available upon request.
} 
We now turn to exploring the patterns of net employment growth for firm age. The top panel of Figure 4 shows the results for firm age from columns 3 to 5 in Table 2. Note in the figure that we omit the estimated coefficient for startups since it is much higher (essentially 2). ${ }^{20}$ The panel reveals a relatively weak relationship between firm age and net growth when we exclude startups. These patterns are robust to controlling for firm size. However, in the lower panel of Figure 4, we find that conditional on survival, young firms exhibit substantially higher growth than more mature firms. ${ }^{21}$ This pattern is robust to controlling for firm size and it clearly indicates that the fastest growing continuing firms are young firms under the age of five.

Reconciling the patterns of the upper and lower panel requires investigating the relationship between firm age and firm exit. That is, the firms not included in the lower panel of Figure 4 relative to the upper panel for firms aged 1 and higher are firm exits. Note that firm entrants are not driving the large difference in patterns across the upper and lower panel of Figure 4 since they are not included in either panel. The relationship between firm age and job destruction from firm exit is reported in Figure $5^{22}$ where it is apparent that young firms have much higher firm exit rates than more mature firms.

Taken together, Figures 4 and 5 show an "up or out” pattern for young firms that is robust to controlling for firm size (and robust to whichever size class method is used). This "up or out" pattern highlights that the net patterns by firm age depicted in the top panel of Figure 4 mask rich dynamics of young firms. This dynamic is an important feature of market based economies and

\footnotetext{
${ }^{20}$ Recall that at the firm-level the net growth rate for a firm startup is equal to 2 using the DHS methodology. The estimated coefficient in Table 2 for all startups is close to 2 but not identical to 2 in all cases since this is a relative coefficient to the most mature firms after also controlling for industry and year effects.

${ }^{21}$ Like Figure 3, Figure 4 reports estimated coefficients (available upon request) for specifications analogous to Table 2 but focusing on continuing firms only. Given the non-parametric specifications, these and subsequent figures are showing conditional means by firm age (and firm size as relevant).

${ }_{22}^{22}$ The figure plots estimated coefficients for specifications analogous to Table 2 (e.g., including firm size, firm age, industry and year effects) but with the dependent variable equaling job destruction from firm exit at the firm level. The remaining figures follow this same pattern with the same RHS variables but alternative LHS variables. Regression coefficients available upon request.
} 
is consistent with predictions in models of market selection and learning (e.g., see Jovanovic (1982), Hopenhayn (1992) and Ericson and Pakes (1995)). The “up or out” pattern of young firms also helps put the job creation from startups in perspective. Each wave of firm startups creates a substantial number of jobs. In the first years following entry, many startups fail (the cumulative employment weighted exit rate derived from Figure 5 implies that about 40 percent of the jobs created by startups are eliminated by firm exits in the first five years) but the surviving young businesses grow very fast. ${ }^{23}$ In this respect, the startups are a critical component of the experimentation process that contributes to restructuring and growth in the U.S. on an ongoing basis.

\subsection{Employment Volatility by Firm Age and Firm Size}

We now turn to the patterns of gross job creation and destruction by firm age and firm size. Our interest is multi-fold. For one, the results reported above already show that there are interesting differences across continuing, entering and exiting firms in net growth rates so it makes sense to look more broadly and decompose the effects on job creation and destruction. We are also interested in the relationship between employment volatility and firm size and firm age which in the present analysis can be measured using rates of gross job creation and destruction. When looking at employment volatility, it is instructive to examine patterns at both the firm and establishment-level. The reason is that there can be within firm reallocation for even stable firms as some establishments in a given firm expand while others contract.

Figure 6 shows the patterns of job creation and destruction rates for firms and establishments by firm age. Interestingly, the patterns look quite similar at the firm and establishment levels although the magnitudes are somewhat higher at the establishment-level

\footnotetext{
${ }^{23}$ Although the growth from the survivors does not fully compensate for the exits. The cumulative net growth rate implied by Figure 4 is about -7 percent in the first five years after entry. Note however that this still implies five years after entry a typical cohort has contributed a substantial number of jobs.
} 
given that the latter also captures within-firm creation and destruction across establishments in the same firm. ${ }^{24}$ It is apparent that, at both the firm and establishment-level, volatility is higher at young firms as the pace of creation and destruction falls monotonically by firm age with or without size controls. Controlling for firm size has relatively modest effects. The most apparent effects are in the relationship between job destruction and firm age. Here we observe that controlling for firm size tends to reduce the rate of decline of job destruction with firm age especially when using current size controls.

We now turn to the patterns of job creation and destruction by firm size. The upper panel of Figure 7 shows the patterns for firm-level creation and destruction and the lower panels the patterns for establishment-level creation and destruction. We find that whether or not one controls for age effects and for both size class methods, job destruction tends to decline with firm size. However, the patterns for job creation are more sensitive to controlling for firm age. Job creation falls especially rapidly with firm size when not controlling for firm age but this effect largely disappears with firm age controls. These results highlight the asymmetry in job creation and destruction patterns for small firms. Controlling for age, small firms are more likely to destroy jobs but are not more likely to create jobs.

Turning to the establishment-level patterns, we find higher establishment-level job creation (and to a lesser extent job destruction) rates at larger firms once controls for firm age are included. The implication is that, abstracting from firm age effects, establishments at large firms create jobs at a faster rate than establishments of small firms and that the establishments of large firms are not necessarily less volatile than the establishments of small firms.

\footnotetext{
${ }^{24}$ The establishment-level creation and destruction rates are only necessarily higher than the analogous firm-level creation and destruction rates at the unconditional means (reported for the 16+ group). For the other groups, industry and year controls may be different at the establishment and firm level so this pattern need not hold.
} 
The analysis of the creation and destruction margins again highlights several important points for the job creation debate. First, the symmetry in job creation and destruction patterns for young firms and establishments; that is, young firms and establishments have relatively high rates of job creation and destruction which translate into high number of jobs being simultaneously created and destroyed in the economy as shown in Figure 1. Second, the asymmetric response in job creation and destruction patterns for small firms. Small firms, once we account for the effects of age, do not have particularly high rates of job creation but relatively high rates of job destruction. Third, when we turn to establishment-level measures of volatility, establishment volatility is larger at large firms than small firms once we control for firm age. ${ }^{25}$

\subsection{The Entry and Exit Margins: Establishment vs. Firm}

Figure 8 shows establishment entry and exit by firm age. The upper panel shows that establishment entry exhibits a slight tendency to increase with firm age that is mitigated when one controls for firm size. By contrast, the lower panel shows a strong firm age effect in job destruction from establishment exit with exits falling monotonically with firm age. Taking these patterns together with those of Figure 6 above we see that young firms disproportionally create jobs by expanding existing establishments rather than opening new ones. By contrast young and mature firms seem equally likely to shed jobs by contracting establishments and by shutting them down. Additionally, in comparing the establishment-level patterns in Figure 8 to the firm-level patterns in Figure 5, we see that job destruction from establishment exit declines less rapidly with firm age than does job destruction from firm exit. Mature firms are much less likely to exit than young firms but establishments of mature firms have relatively high exit rates compared to establishments of young firms conditional on other observable factors (Dunne et. al. (1989) also

\footnotetext{
${ }^{25}$ When we aggregate employment to the level of the firm we net out within firm patterns of establishment job creation and destruction. The exception of course is for single unit firms where firm and establishment will net the same measures.
} 
found this result for U.S. manufacturing). In a related way, the patterns in Figure 8 help account for the patterns in Figure 6. That is, job creation and destruction at the establishment level decline less rapidly with firm age than job creation and destruction at the firm level since mature firms have relatively high entry and exit rates of establishments.

Figure 9 shows results from regressions where we focus on the entry and exit components of job creation and destruction by firm size. The upper left hand panel shows that without firm age controls, firm entry rates are much higher in the smallest size classes. Controlling for firm age wipes out these patterns completely. ${ }^{26}$ By contrast, the upper right panel shows that job destruction from firm exit tends to fall with firm size. This rate of decline is largely robust to specification and the inclusion of age controls.

The lower panels of Figure 9 show the analogous relationships of establishment entry and exit by firm size. Establishment entry tends to fall with firm size when not controlling for firm age and this reflects the obvious relationship between firm entry and establishment entry. However, after controlling for firm age, we observe establishment entry rising with firm size. The lower right panel of Figure 9 shows that job destruction from establishment exit tends to decline with firm size although the rate of decline is modest after the smallest size classes. The analysis of the entry and exit margins reveals several interesting patterns. First, looking at establishments we find young firms are less likely to exhibit job creation from opening new establishment than are mature firms. Young firms, however, disproportionally create jobs by expanding existing establishments. Large firms are more likely to open new establishments when we control for firm age. Second, firm entry rates are much higher for the

\footnotetext{
${ }^{26}$ Indeed, it might seem surprising that there are any firm entry patterns once we control for firm age. The reason is that for the very smallest firms that there is some modest amount of re-entry that occurs. That is, for small firms we sometimes see the firm enter, exit and then re-enter at a later date. In Davis et. al. (2009), this pattern is shown in part to be due to some very small employer firms alternating between being employer and non-employer firms.
} 
smallest size classes, but this simply reflects the fact that new firms tend to be small. Firm exit is also more likely for smaller firms and this holds even after controlling for firm age.

\section{Concluding Remarks}

There is a widespread popular perception that small businesses create more or even most jobs in the U.S. We argue, as has the earlier literature, that the popular question of "what fraction of net new jobs is created by small businesses?” is not well posed. In addition, until the Census Bureau’s Business Dynamic Statistics (BDS) became available, publicly available data on firm size and growth tended to confirm the popular perception.

The BDS contains tabulations by firm size and firm age. Thus, for the first time data users can examine both net and gross job creation and destruction by firm size and age. As we showed in Figure 1, BDS data demonstrate that, in addition to previous concerns about measurement issues, not accounting for firm age can lead to misleading inferences about the role of firm size in job creation.

In this paper we explored the basic patterns in Figure 1 more deeply and rigorously using the source data for the BDS, the LBD. We find some evidence in support of the popular perception that small businesses create more jobs along the following lines. If one looks at the simple relationship between firm size and net growth rates, there is evidence that net growth rates tend to be higher for smaller as opposed to larger businesses. This is the case using widely available data such as the Census Bureau’s SUSB, but can also be obtained through careful analysis of micro data as both NWZ and we demonstrate. Of course, the caveats raised over years such as the role of regression to the mean still apply. Using our preferred firm size classification that we argue is more robust to such concerns, the inverse relationship between net growth rates and size remains but is not overwhelming. 
As the results from Figure 1 would suggest, the more important and robust finding is the role of firm age. We find that once we control for firm age, the negative relationship between firm size and net growth disappears and may even reverse sign as a result of relatively high rates of exit amongst the smallest firms. Our findings suggest that it is particularly important to account for business startups. Business startups account for roughly 3 percent of U.S. total employment in any given year. While this is a reasonably small share of the stock, it is large relative to the net flow which averages around 2.2 percent per year. Startups tend to be small so most of the truth to the popular perception is driven by the contribution of startups, which are primarily small, to net growth.

We also find rich dynamics among the young firms in the U.S. that help put the contribution and role of startups into perspective. Young firms exhibit high rates of gross job creation and destruction. Consistent with this pattern, we find that young firms have very high job destruction rates from exit so that after five years about 40 percent of the jobs initially created by startups have been eliminated by exit. However, we also find that, conditional on survival, young firms grow more rapidly than their more mature counterparts. In combination, our findings suggest a rich "up or out” dynamic of startups and young firms that is consistent with models of market selection and learning. Understanding the process of job creation by private sector businesses requires understanding this dynamic. Policies that favor various simply defined classes of businesses (e.g., by size) and ignore this fundamental dynamic will likely have limited success.

Most of our focus in the analysis is on the net growth rate patterns by firm size and firm age (along with the underlying different margins of adjustment). However, we also show that large, mature businesses account for a large fraction of jobs. Firms over 10 years old and have 
more than 500 workers account for about 45 percent of all jobs in the U.S. private sector. In turn, we show that these large, mature firms account for almost 40 percent of job creation and destruction. As shown in Figure 1, the share of jobs created and destroyed by different groups of firms is roughly their share of total employment. However, this is hardly the whole story as much of the analysis in the paper shows that some groups disproportionately create and destroy jobs. For example, firm startups account for only 3 percent of employment but almost 20 percent of gross job creation. Young and small businesses disproportionately create and destroy jobs and large mature firms exhibit robust adjustments along the establishment entry and exit margins.

In closing, we think our findings help interpret the popular perception of the role of small businesses as job creators in a manner that is consistent with theories that highlight the role of business formation, experimentation, selection and learning as important features of the U.S. economy. ${ }^{27}$ Viewed from this perspective, the role of business startups and young firms is part of an ongoing dynamic of U.S. businesses that needs to be accurately tracked and measured on an ongoing basis. Measuring and understanding the activities of startups and young businesses, the frictions they face, their role in innovation and productivity growth, how they fare in economic downturns and credit crunches all are clearly interesting areas of inquiry given our findings of the important contribution of startups and young businesses.

In a related manner, it is important to not focus only on jobs per se but also on the role of these dynamics in the patterns of productivity and earnings behavior in the U.S. We also need to develop the data and associated analyses that will permit investigating the complex relationships between young and mature (as well as small and large) businesses. It may be, for example, that the volatility and apparent experimentation of young businesses that we have identified is critical

\footnotetext{
${ }^{27}$ There has, of course, been substantial theoretical development along these lines (e.g., Jovanovic (1982), Hopenhayn (1992) and Ericson and Pakes (1995)) and our findings, like others in the literature (e.g., Dunne, Roberts and Samuelson (1989) and DHS) provide broad empirical support for this class of models and ideas.
} 
for the development of new products and processes that are in turn used by (and perhaps acquired by) the large and mature businesses that account for most economic activity. Viewed from this perspective, our findings show that the LBD and the BDS are rich databases to track U.S. business dynamics but it is also clear that additional information about the productivity and earnings dynamics as well as business-to-business relationships need to be added to these databases and related analyses. 


\section{References}

Acs, Zoltan J., Catherine Armington, and Alicia Robb, 1999, "Measures of Job Flow Dynamics in the U.S. Economy" U.S. Small Business Administration, January.

Aldrich, Howard, Arne Kalleberg, Peter Marsden and James Casell, 1988, "In Pursuit of Evidence: Five Sampling Procedures for Locating New Businesses", Journal of Business Venturing, 4, 367-386.

Becker. Randy A., John Haltiwanger, Ron S. Jarmin, Shawn D. Klimek and Daniel J. Wilson, 2006, “Micro and Macro Data Integration: the Case of Capital”, in A New Architecture for the U.S. National Accounts, (Jorgenson, Landefeld and Nordhaus eds), NBER/University of Chicago Press,

Birch, David L., 1979, The Job Generation Process, unpublished report prepared by the MIT Program on Neighborhood and Regional Change for the Economic Development Administration, U.S. Department of Commerce, Washington, DC,

Birch, David L., 1981, “Who Creates Jobs?” The Public Interest 65, 3-14.

Birch, David L., 1987, Job Creation in America: How Our Smallest Companies Put the Most People to Work, Free Press, New York.

Birley, Sue, 1984, "Find the Firm", Proceedings of the Academy of Management Meetings. Brown, Charles, James Hamilton, and James Medoff, 1990, Employers Large and Small, Cambridge: Harvard University Press.

Butani, Shail, Richard Clayton, Vinod Kapani, James Spletzer, David Talan, and George Werking, 2006, “Business Employment Dynamics: Tabulations by Employer Size” Monthly Labor Review, February 2006 
Davis, Steven J., John Haltiwanger and Scott Schuh, 1996, Job Creation and Destruction, MIT Press.

Davis, Steven J., John Haltiwanger, Ron S. Jarmin and Javier Miranda, 2007, “Volatility and Dispersion in Business Growth Rates: Publicly Traded vs. Privately Held Firms.” NBER Macroeconomics Annual 2006, vol. 21.

Davis, Steven J., John Haltiwanger, C.J. Krizan, Ron Jarmin, Javier Miranda, Al Nucci, and Kristin Sandusky, 2009, "Measuring the Dynamics of Young and Small Businesses: Integrating the Employer and Non-Employer Businesses” in Producer Dynamics: New Evidence from Micro Data, (Dunne, Jensen and Roberts, eds.) NBER/University of Chicago Press.

Doms, Mark E., Ron S. Jarmin, and Shawn D. Klimek, 2004, “Information technology investment and firm performance in US retail trade.” Economics of Innovation and New Technology, vol. 13(7), pp. 595-613.

Dunne, Timothy, Mark Roberts and Larry Samuelson, 1989, "The Growth and Failure of U.S. Manufacturing Plants,” Quarterly Journal of Economics, vol. 104 (4), pp. 671-98.

Ericson, Richard and Ariel Pakes, 1995, “ Markov-Perfect Industry Dynamics: A Framework for Empirical Work”, The Review of Economic Studies, Vol. 62, No. 1. pp. 53-82

Evans, David S., 1987, “The Relationship between Firm Growth, Size, and Age: Estimates for 100 Manufacturing Industries,” Journal of Industrial Economics 35, pp. 567-581.

Foster, Lucia, John Haltiwanger, and C.J. Krizan, 2006, “Market Selection, Reallocation and Restructuring in the U.S. Retail Trade Sector in the 1990s,” The Review of Economics and Statistics, vol. 88(4), pp. 748-758. 
Friedman, Milton, 1992, "Do Old Fallacies Ever Die?,” Journal of Economic Literature ,30(4), 2139-2132.

Haltiwanger, John, Ron Jarmin and Javier Miranda, 2009 “Business Dynamics Statistics: An Overview” Marion Ewing Kauffman Foundation BDS Briefs. http://www.kauffman.org/uploadedFiles/BDS_handout_011209.pdf

Haltiwanger, John and C.J. Krizan, 1999 “Small Business and Job Creation in the United States: The Role of New and Young Businesses” in Are Small Firms Important?: Their Role and Impact, edited by Zoltan Acs, Kluwer Academic Publishing Company.

Hopenhayn, Hugo. 1992. “Entry, Exit, and Firm Dynamics in Long Run Equilibrium”, Econometrica, 60(5): 1127-50.

Jarmin, Ron S., Shawn D. Klimek and Javier Miranda, 2009, “The Role of Retail Chains: National, Regional and Industry Results,” in Dunne, Jensen and Roberts (eds.), Producer Dynamics: New Results from Micro Data, University of Chicago Press for the NBER.

Jarmin, Ron S., and Javier Miranda, 2002, “The Longitudinal Business Database”, CES Working Paper 02-17.

Jovanovic, Boyan. 1982. "Selection and the Evolution of Industry”, Econometrica, 50(3): 649670.

Neumark, David, Brandon Wall, and Junfu Zhang, 2009, "Do Small Businesses Create More Jobs? New Evidence for the United States from the National Establishment Time Series", Review of Economics and Statistics, (forthcoming).

Okolie, Cordelia, 2004, "Why Size Class Methodology Matters in Analyses of Net and Gross Job Flows." Monthly Labor Review, July. 
Olley, Steven and Ariel Pakes, 1996, The Dynamics of Productivity in the Telecommunications Equipment Industry, Econometrica, 64(6): 1263-1310.

Sutton, John, 1997 “Gibrat’s Legacy,” Journal of Economic Literature 35, 40-59.

Tornqvist, Leo, Pentti Vartia and Yrjo Vartia, 1985, "How Should Relative Change Be Measured?” American Statistician, February, 39:1, pp. 43-46. 
Figure 1: Shares of Employment, Job Creation and Destruction by Broad Firm (Current) Size and Age Classes - Annual Average Rates 1992-2005

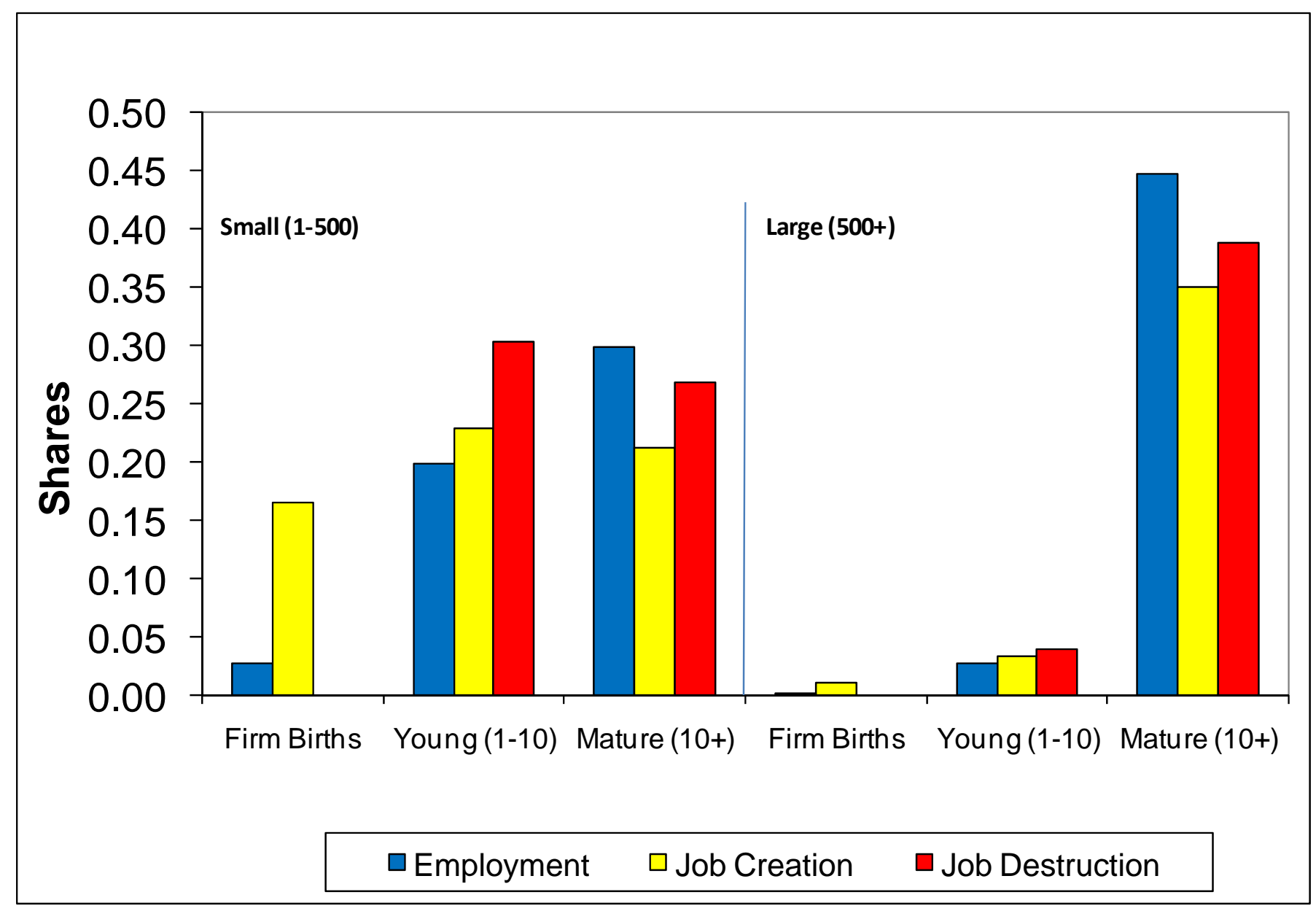




\begin{tabular}{|c|c|c|c|c|c|c|c|}
\hline \multicolumn{8}{|c|}{$\begin{array}{ll}\text { Figure } 2 \\
\end{array}$} \\
\hline \multicolumn{2}{|c|}{ Establishment Dynamics } & Firm & $\begin{array}{l}\text { Establishments } \\
\text { in } \mathrm{t}-1\end{array}$ & $\begin{array}{l}\text { Establishments } \\
\text { in } \mathrm{t}\end{array}$ & $\begin{array}{l}\text { Employment } \\
\text { in } t-1\end{array}$ & $\begin{array}{c}\text { Employment in } \\
t\end{array}$ & $\begin{array}{c}\text { Net } \\
\text { Change }\end{array}$ \\
\hline \multirow[t]{2}{*}{ Year t-1 } & Year t & A & 3 & 1 & 580 & 450 & -130 \\
\hline & & B & 2 & 4 & 140 & 285 & 145 \\
\hline A & A & C & 0 & 1 & 0 & 200 & 200 \\
\hline $1(400)$ & $1(450)$ & D & 1 & 0 & 15 & 0 & -15 \\
\hline $2(100)$ & & E & 2 & 1 & 750 & 600 & -150 \\
\hline \multirow{2}{*}{$3(80)$} & & $\mathrm{F}$ & 1 & 1 & 75 & 80 & 5 \\
\hline & B & G & 1 & 0 & 100 & 0 & -100 \\
\hline B & $2(75)$ & $\mathrm{H}$ & 0 & 1 & 0 & 120 & 120 \\
\hline $4(100)$ & $4(100)$ & Total & 10 & $\overline{9}$ & 1660 & 1735 & 75 \\
\hline \multirow[t]{3}{*}{$5(40)$} & $5(80)$ & & & & & & \\
\hline & $6(30)$ & & & & & & \\
\hline & $\frac{C}{7(200)}$ & Firm & $\begin{array}{l}\text { Firm-Level DHS } \\
\text { Net Growth Rate } \\
\text { (Including M\&A) }\end{array}$ & $\begin{array}{r}\text { Firm DHS Net G } \\
\text { Based on } \mathrm{T} \\
\text { Establishment } \mathrm{G}\end{array}$ & $\begin{array}{l}\text { Growth Rate } \\
\text { Veighted } \\
\text { Growth Rates }\end{array}$ & Establishment & $\begin{array}{l}\text { Establishment-Level } \\
\text { DHS Net Growth Rate }\end{array}$ \\
\hline D & & $\overline{\mathrm{A}}$ & -0.2524 & -0.064 & & 1 & 0.1176 \\
\hline \multirow[t]{2}{*}{$8(15)$} & & B & 0.6824 & 0.171 & & 2 & -0.2857 \\
\hline & & C & 2.0000 & 2.000 & & 3 & -2.0000 \\
\hline E & E & D & -2.0000 & -2.000 & & 4 & 0.0000 \\
\hline \multirow{2}{*}{\begin{tabular}{|c|}
$9(500)$ \\
$10(250)$ \\
\end{tabular}} & $9(600)$ & E & -0.2222 & $-0.222-x-3 x$ & & 5 & 0.6667 \\
\hline & & $\mathrm{F}$ & 0.0645 & 0.064 & & 6 & 2.0000 \\
\hline \multirow{2}{*}{$F$} & & G & -2.0000 & & & 7 & 2.0000 \\
\hline & $\mathbf{F}$ & $\mathrm{H}$ & 2.0000 & 0.181 & & 8 & -2.0000 \\
\hline \multirow[t]{2}{*}{$11(75)$} & $11(80)$ & & & & & 9 & 0.1818 \\
\hline & & & & & & 10 & -2.0000 \\
\hline G & H & & & & & 11 & 0.0645 \\
\hline \multirow[t]{5}{*}{$12(100)$} & $12(120)$ & & & & & 12 & 0.1818 \\
\hline & & Aggregate Net Growth & 0.0442 & $\overline{0.044}$ & & & 0.0442 \\
\hline & & From Births & 0.1885 & 0.117 & & & 0.1355 \\
\hline & & From Deaths & -0.0677 & -0.008 & & & -0.2032 \\
\hline & & From Continuers & -0.0766 & -0.064 & & & 0.1119 \\
\hline
\end{tabular}


Figure 3: The Relationship between Net Growth and Firm Size

Panel A: All Firms

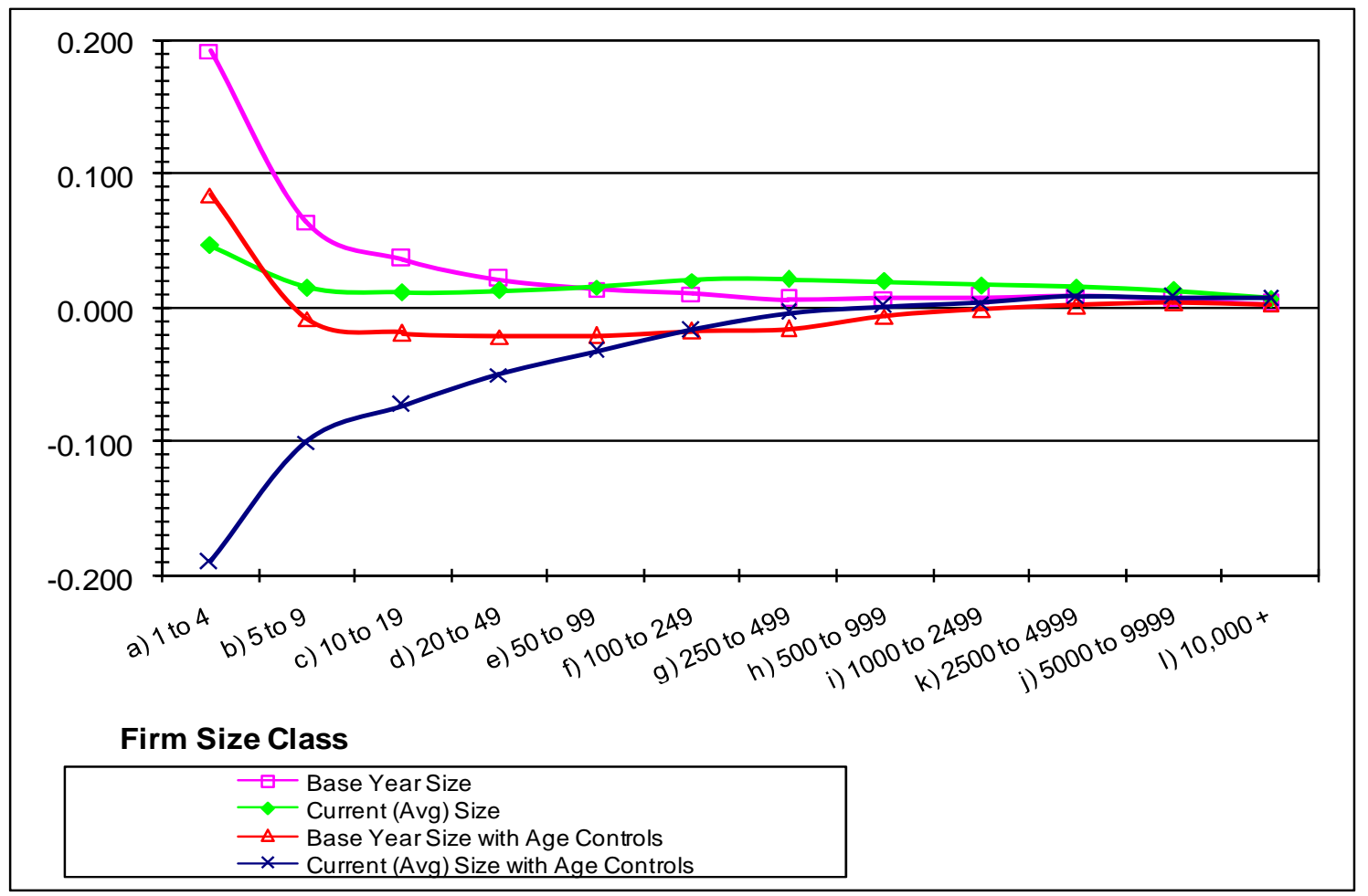

Panel B: Continuing Firms Only

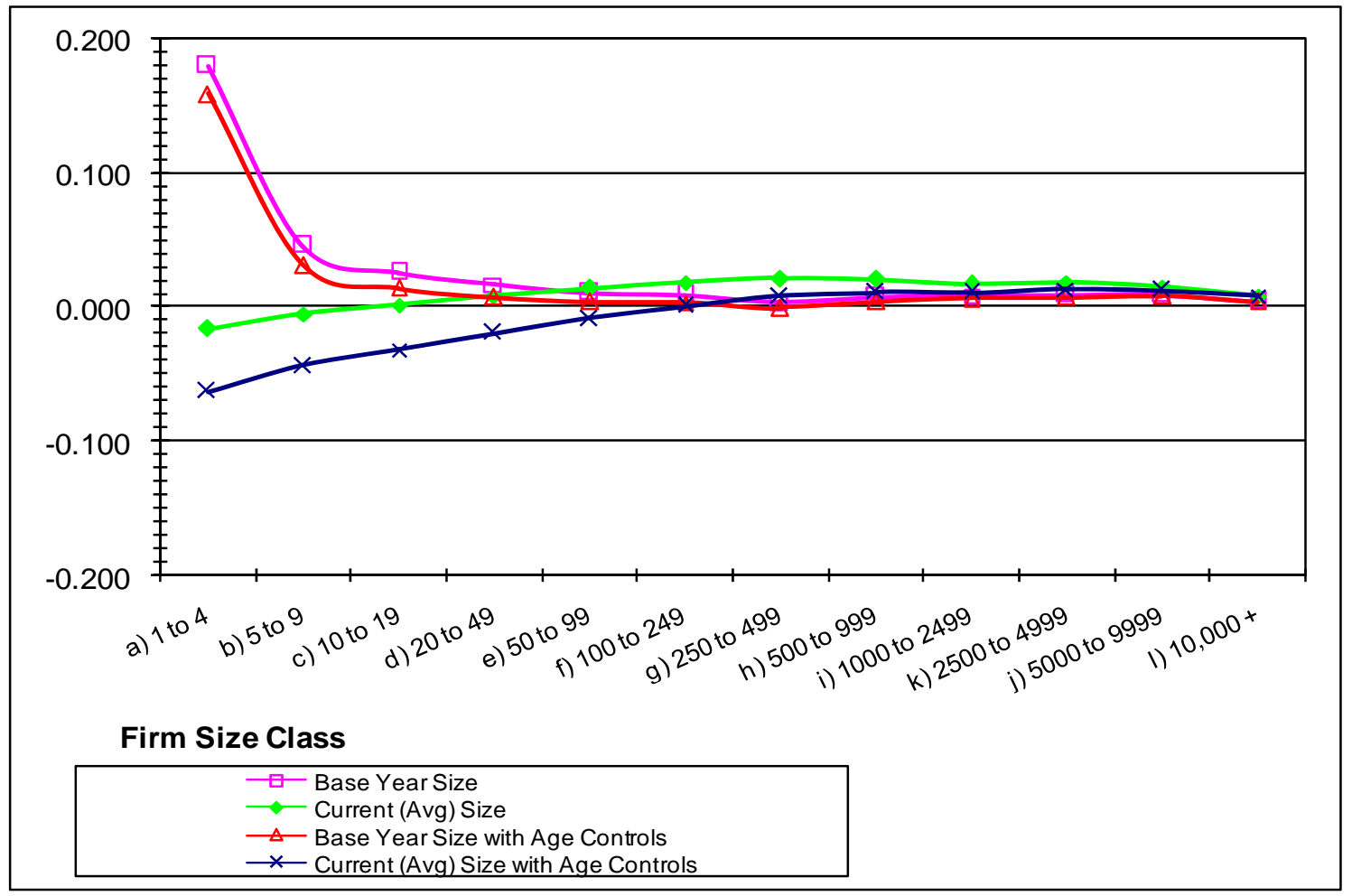


Figure 4: The Relationship between Net Employment Growth and Firm Age
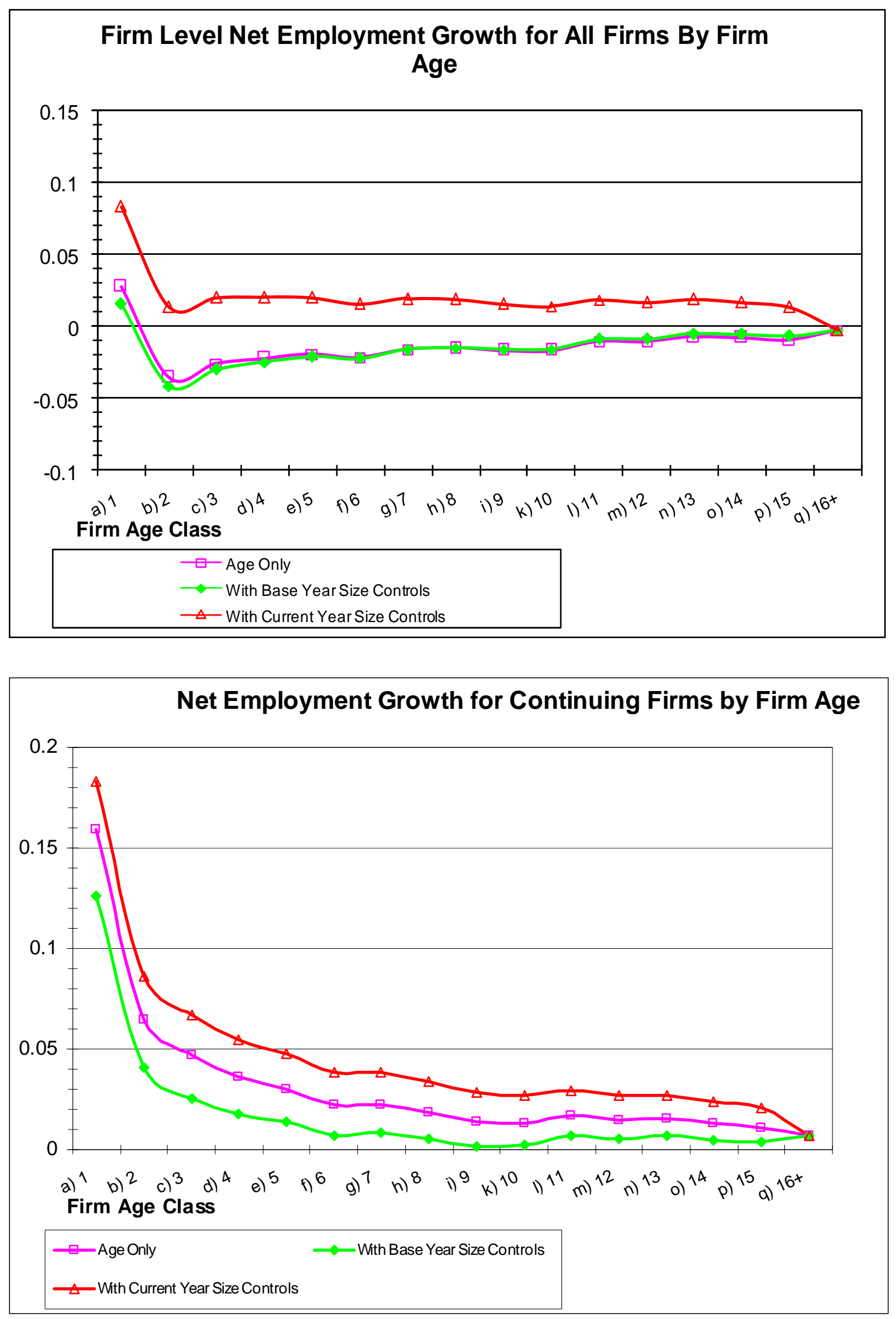
Figure 5: Firm Exit by Firm Age

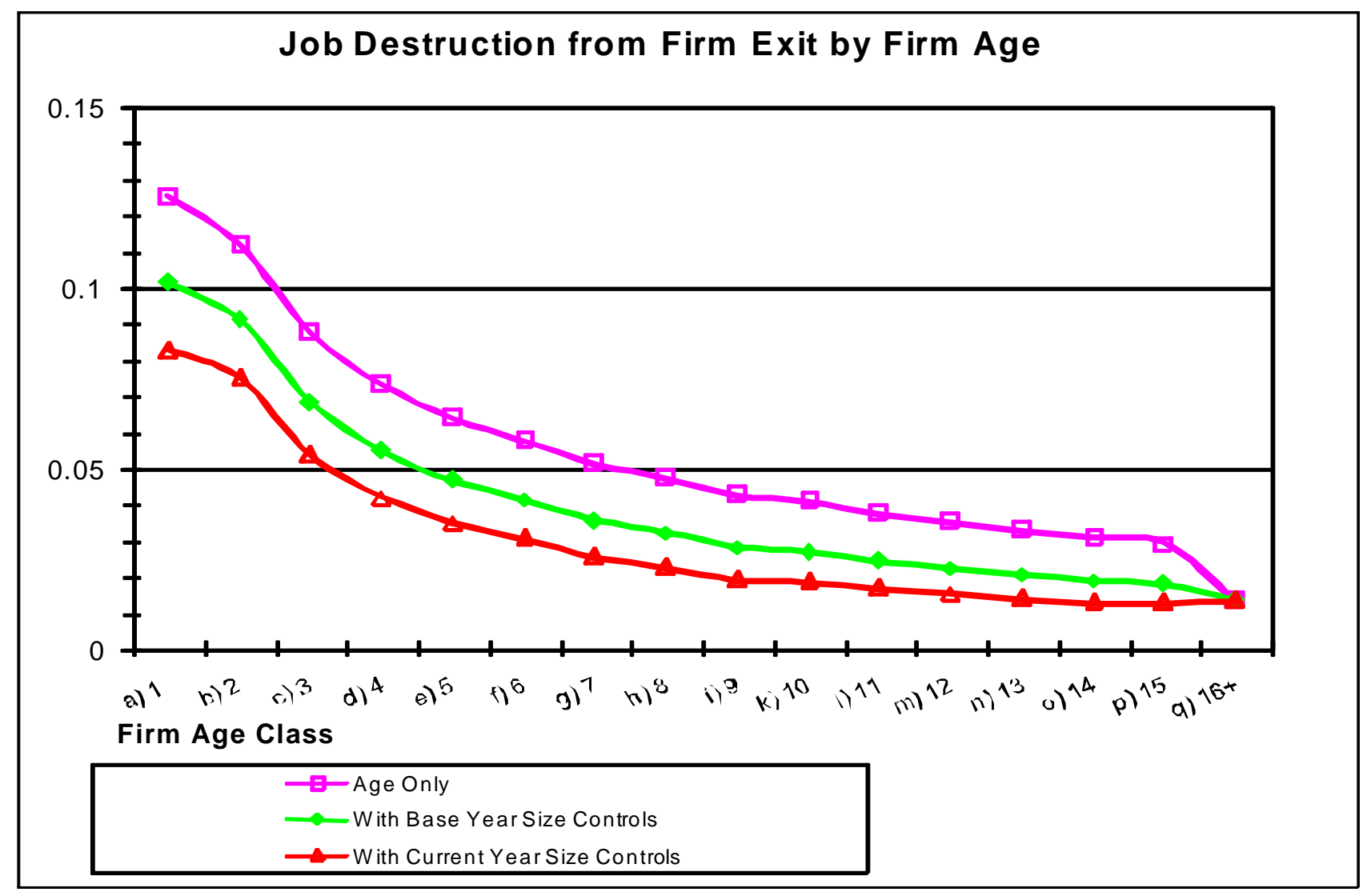


Figure 6: Job Creation and Destruction at the Firm and Establishment Level by Firm Age
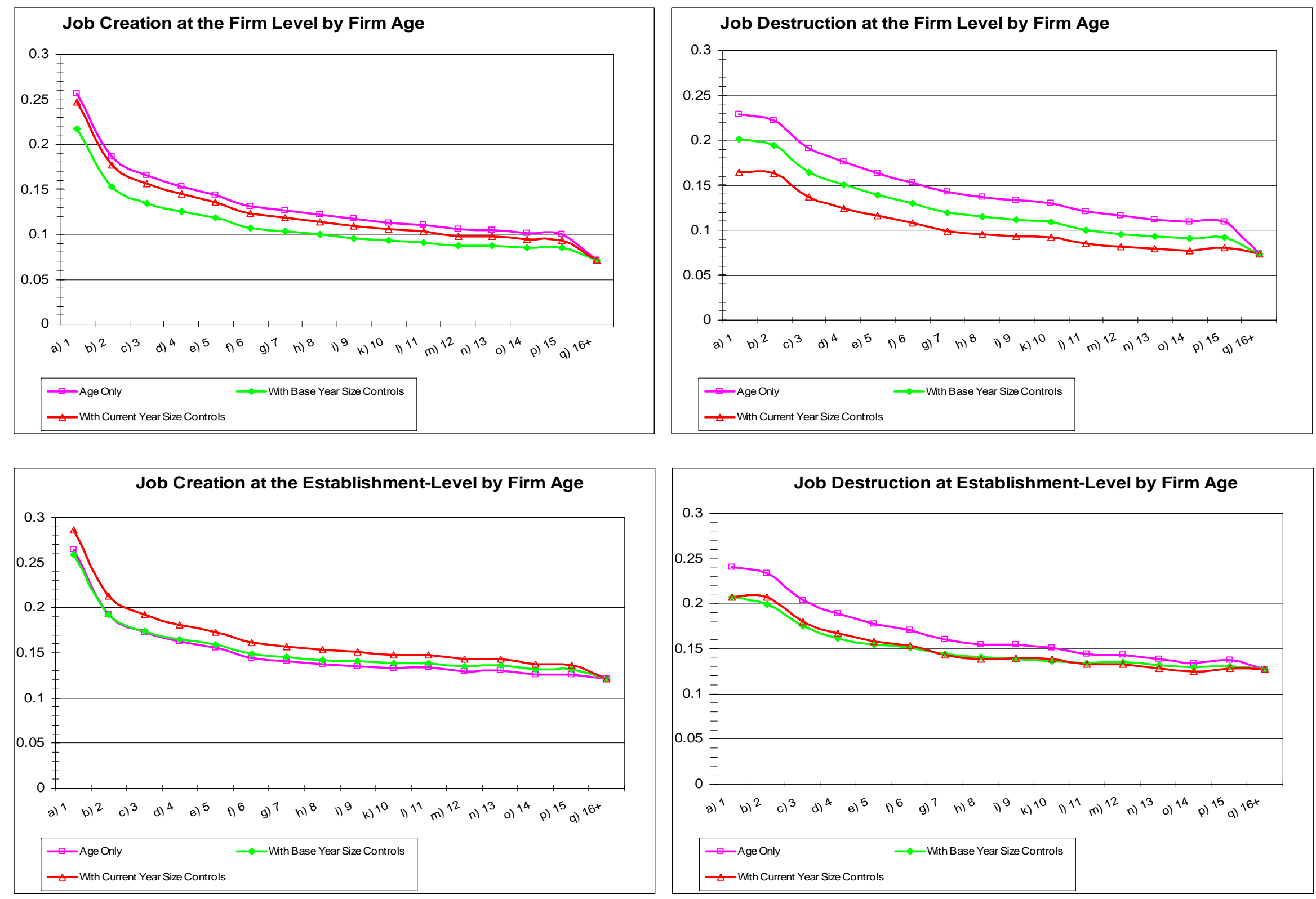
Figure 7: Job Creation and Destruction at the Firm and Establishment Level by Firm Size
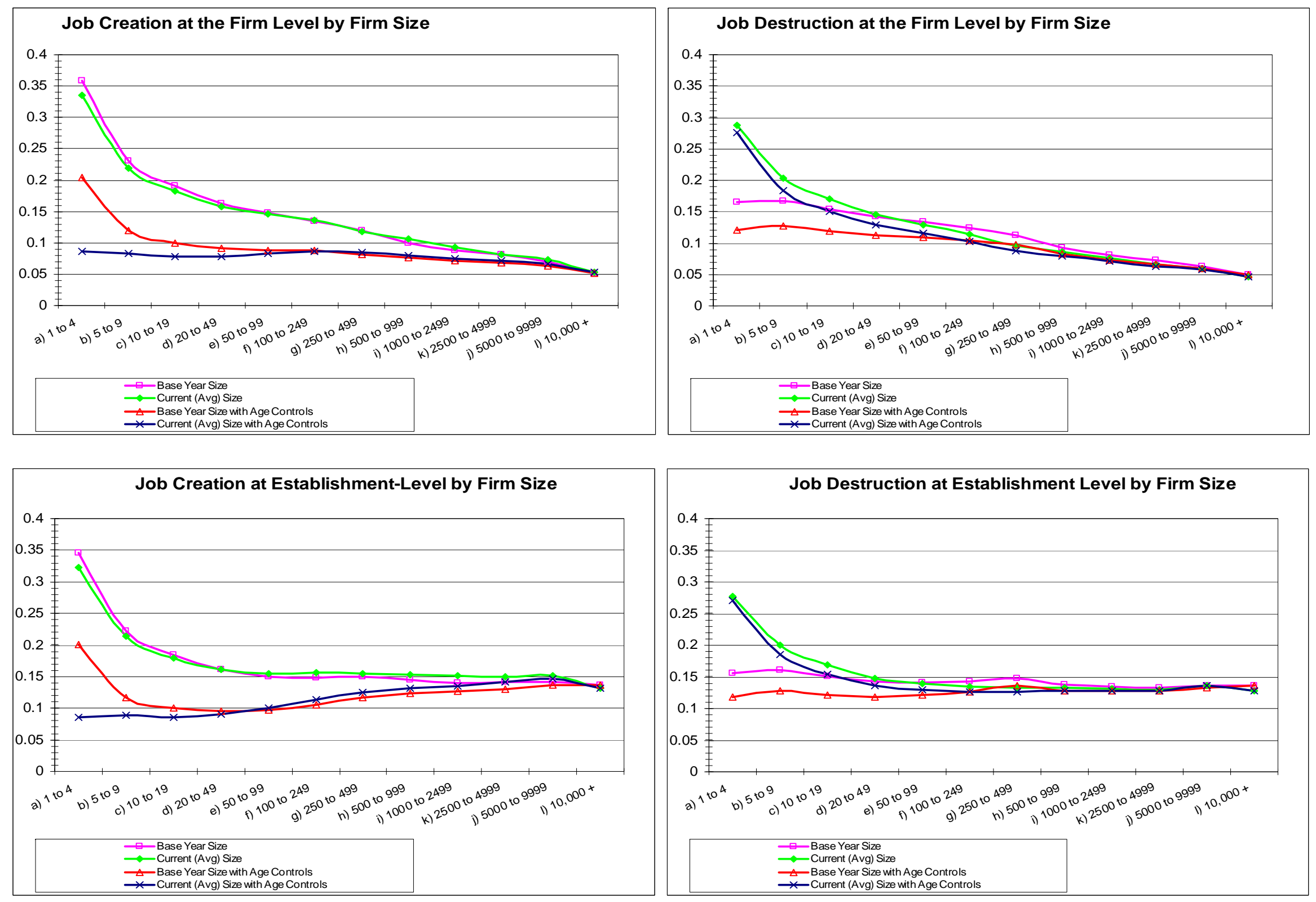
Figure 8: Establishment Entry and Exit by Firm Age
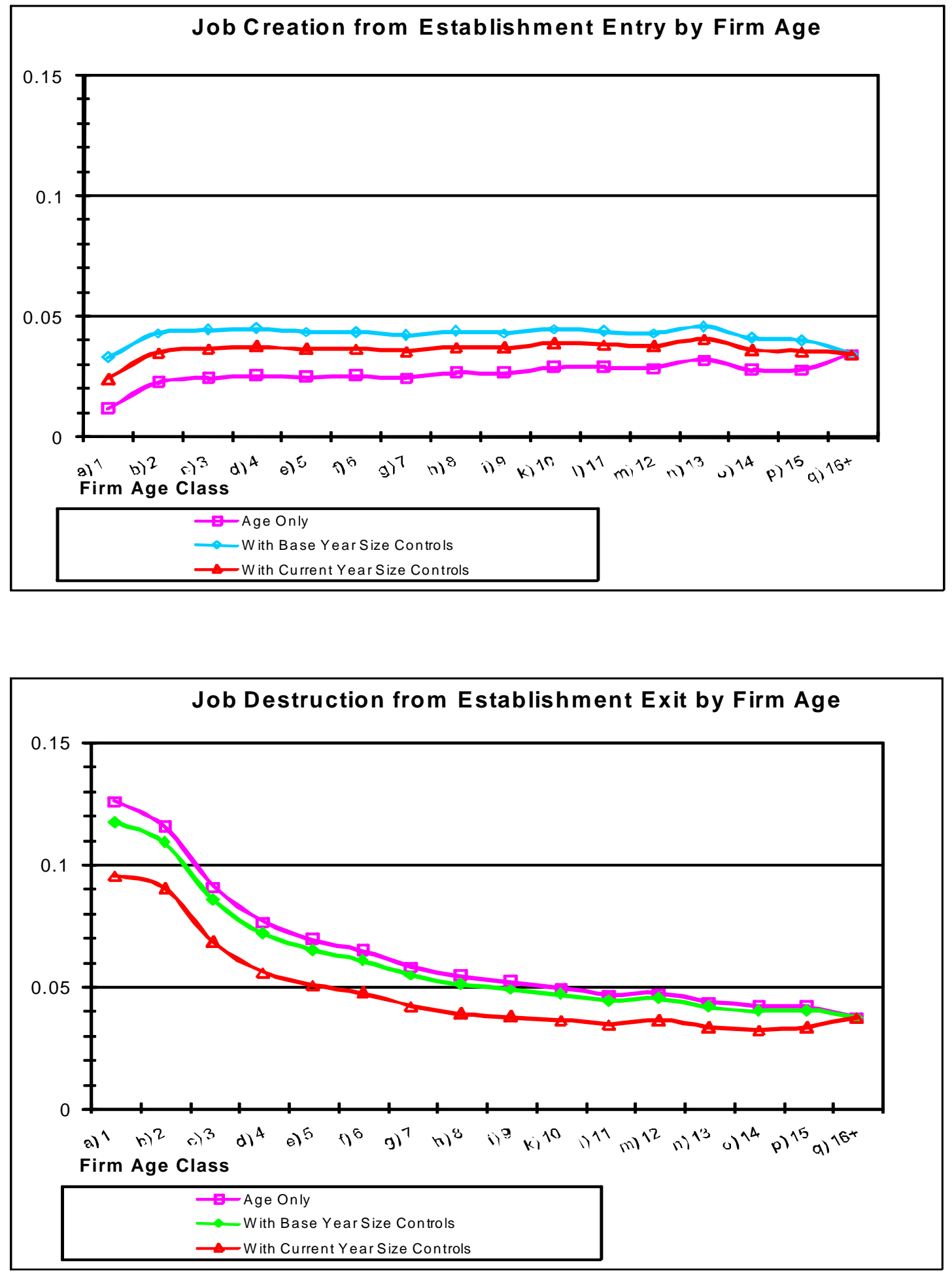
Figure 9: Firm and Establishment Entry and Exit by Firm Size
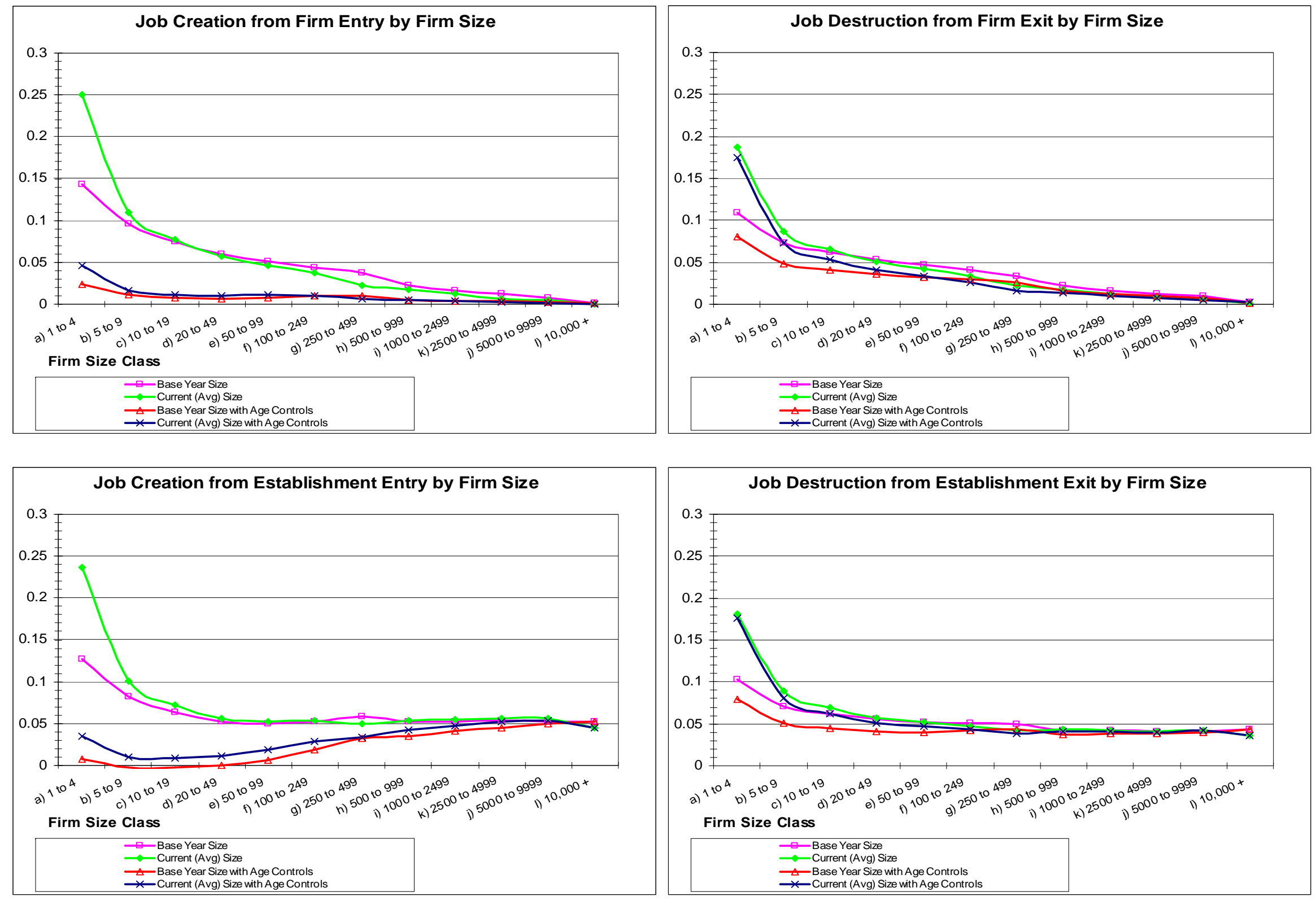
Table 1 Net Job Creation by Firm Size and Firm Age, U.S. Private Sector, 2005

\begin{tabular}{|c|c|c|c|c|c|c|c|c|c|c|c|c|c|}
\hline Firm Age & a) 1 to 4 & Size (Base & $\begin{array}{l}\text { ear) } \\
\text { c) } 10 \text { to } \\
19\end{array}$ & $\begin{array}{l}\text { d) } 20 \text { to } \\
49\end{array}$ &  & f) $\begin{array}{l}100 \text { to } \\
249\end{array}$ & g) $\begin{array}{c}250 \text { to } \\
499\end{array}$ & $\begin{array}{c}\text { h) } 500 \text { to } \\
999\end{array}$ & $\begin{array}{l}\text { i) } 1000 \text { to } \\
2499\end{array}$ & j) $\begin{array}{l}2500 \text { to } \\
4999\end{array}$ & $\begin{array}{c}\text { k) } 5000 \text { to } \\
9999\end{array}$ & I) $10000+$ & All \\
\hline a) 0 & 731,515 & 503,644 & 498,317 & 553,181 & 313,511 & 292,348 & 157,120 & 151,518 & 186,087 & 131,178 & $\mathrm{D}$ & $\mathrm{D}$ & \begin{tabular}{|l|}
$3,518,419$ \\
\end{tabular} \\
\hline b) 1 & 79,759 & $-12,547$ & $-20,836$ & $-47,837$ & $-41,006$ & $-57,188$ & $-48,830$ & $-5,476$ & $-14,532$ & $-20,131$ & 211 & -408 & $-188,821$ \\
\hline c) 2 & 26,506 & $-24,840$ & $-31,883$ & $-44,488$ & $-26,738$ & $-18,026$ & $-9,049$ & $-13,579$ & $-23,615$ & $-12,782$ & $\mathrm{D}$ & $\mathrm{D}$ & $-178,494$ \\
\hline d) 3 & 7,535 & $-22,650$ & $-26,855$ & $-37,824$ & $-15,918$ & $-14,813$ & $-8,981$ & $-7,548$ & $-11,581$ & $-12,114$ & $\mathrm{D}$ & $\mathrm{D}$ & $-150,749$ \\
\hline e) 4 & 20,456 & $-18,442$ & $-23,212$ & $-29,616$ & 641 & $-9,816$ & $-4,301$ & $-5,436$ & -298 & $-4,011$ & $\mathrm{D}$ & $\mathrm{D}$ & $-74,035$ \\
\hline f) 5 & 4,808 & $-19,792$ & $-24,392$ & $-29,425$ & $-14,870$ & $-6,222$ & $-2,449$ & $-6,849$ & -293 & $-3,418$ & $\mathrm{D}$ & $\mathrm{D}$ & $-102,902$ \\
\hline g) 6 to 10 & 14,577 & $-71,332$ & $-99,235$ & $-110,111$ & $-40,652$ & $-1,324$ & $-9,452$ & 5,437 & $-20,693$ & $-13,945$ & $-9,903$ & 17,928 & $-338,705$ \\
\hline h) 11 to 15 & 15,663 & $-47,730$ & $-67,923$ & $-81,876$ & $-40,432$ & $-27,666$ & $-9,530$ & 2,179 & $-2,028$ & 22,441 & 6,140 & 69,409 & $-161,353$ \\
\hline i) 16 to 20 & 5,673 & $-36,856$ & $-58,236$ & $-71,299$ & $-35,979$ & 9,780 & $-5,725$ & 10,200 & 3,204 & 12,615 & 10,491 & 2,158 & $-153,974$ \\
\hline j) 21 to 25 & 2,923 & $-28,173$ & $-42,609$ & $-51,490$ & $-22,246$ & $-13,346$ & 3,901 & 10,269 & 36,484 & 10,075 & 9,889 & $-56,563$ & $-140,886$ \\
\hline k) $26+$ & 1,016 & $-38,599$ & $-71,235$ & $-107,390$ & $-48,873$ & 10,309 & 19,924 & 85,473 & 56,436 & 143,701 & 58,245 & 307,517 & 416,524 \\
\hline m) ALL & 910,431 & 182,683 & 31,901 & $-58,175$ & 27,438 & 164,036 & 82,628 & 226,188 & 209,171 & 253,609 & 90,973 & 360,214 & $2,481,097$ \\
\hline
\end{tabular}

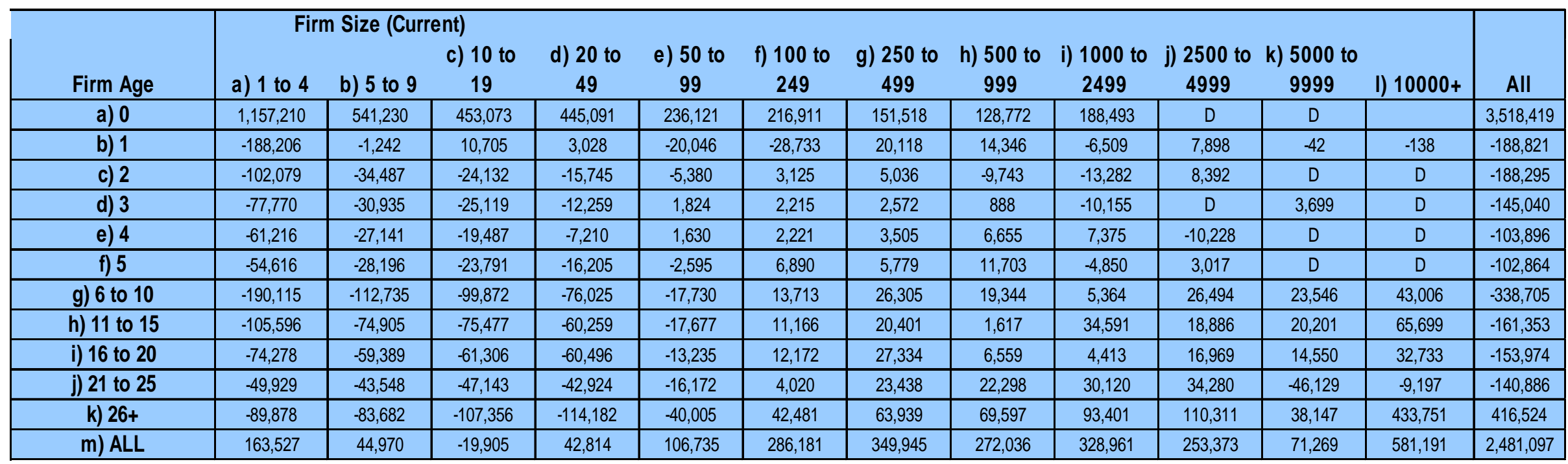

Source: U.S. Census Bureau, Business Dynamics Statistics at http://www.ces.census.gov/index.php/bds/bds_home 


\section{Table 2: Firm-Level Net Employment Growth Regressions}

\begin{tabular}{|c|c|c|c|c|c|c|}
\hline \multicolumn{2}{|c|}{ Parameter } & Base Size & Current Size & Age Only & Base Size + Age & Current Size + Age \\
\hline \multicolumn{7}{|c|}{ Intercept } \\
\hline Size & a) 1 to 4 & 0.189 & 0.040 & & 0.082 & -0.196 \\
\hline Size & b) 5 to 9 & 0.062 & 0.009 & & -0.011 & -0.107 \\
\hline Size & c) 10 to 19 & 0.034 & 0.005 & & -0.021 & -0.080 \\
\hline Size & d) 20 to 49 & 0.019 & 0.006 & & -0.024 & -0.057 \\
\hline Size & e) 50 to 99 & 0.011 & 0.009 & & -0.024 & -0.039 \\
\hline Size & f) 100 to 249 & 0.008 & 0.014 & & -0.020 & -0.023 \\
\hline Size & g) 250 to 499 & 0.004 & 0.014 & & -0.018 & -0.010 \\
\hline Size & h) 500 to 999 & 0.005 & 0.013 & & -0.009 & -0.006 \\
\hline Size & i) 1000 to 2499 & 0.005 & 0.010 & & -0.004 & -0.003 \\
\hline Size & j) 2500 to 4999 & 0.006 & 0.009 & & -0.001 & 0.002 \\
\hline Size & k) 5000 to 9999 & 0.004 & 0.006 & & 0.001 & 0.001 \\
\hline Size & l) $10000+$ & & & & & \\
\hline Age & a. 0 & & & 2.000 & 1.990 & 2.079 \\
\hline Age & b. 1 & & & 0.030 & 0.018 & 0.086 \\
\hline Age & c. 2 & & & -0.033 & -0.039 & 0.016 \\
\hline Age & d. 3 & & & -0.023 & -0.027 & 0.023 \\
\hline Age & e. 4 & & & -0.019 & -0.022 & 0.023 \\
\hline Age & f. 5 & & & -0.017 & -0.018 & 0.023 \\
\hline Age & g. 6 & & & -0.019 & -0.020 & 0.018 \\
\hline Age & h. 7 & & & -0.013 & -0.014 & 0.022 \\
\hline Age & i. 8 & & & -0.012 & -0.012 & 0.022 \\
\hline Age & j. 9 & & & -0.014 & -0.013 & 0.018 \\
\hline Age & k. 10 & & & -0.014 & -0.013 & 0.017 \\
\hline Age & l. 11 & & & -0.008 & -0.006 & 0.021 \\
\hline Age & m. 12 & & & -0.008 & -0.006 & 0.019 \\
\hline Age & n. 13 & & & -0.004 & -0.002 & 0.022 \\
\hline Age & o. 14 & & & -0.005 & -0.003 & 0.020 \\
\hline Age & p. 15 & & & -0.007 & -0.004 & 0.016 \\
\hline Age & u. $16+$ & & & & & \\
\hline R2 & & 0.036 & 0.029 & 0.280 & 0.282 & 0.286 \\
\hline Obs & & $73,396,545$ & $73,396,545$ & $73,396,545$ & $73,396,545$ & $73,396,545$ \\
\hline
\end{tabular}

